\title{
Philippines: Selected Issues Paper
}

This selected issues paper on the Philippines was prepared by a staff team of the International Monetary Fund as background documentation for the periodic consultation with the member country. It is based on the information available at the time it was completed on January 19, 2011. The views expressed in this document are those of the staff team and do not necessarily reflect the views of the government of Philippines or the Executive Board of the IMF.

The policy of publication of staff reports and other documents by the IMF allows for the deletion of market-sensitive information.

\author{
Copies of this report are available to the public from \\ International Monetary Fund • Publication Services \\ $70019^{\text {th }}$ Street, N.W. • Washington, D.C. 20431 \\ Telephone: (202) 623-7430 • Telefax: (202) 623-7201 \\ E-mail: publications@imf.org Internet: http://www.imf.org
}

\section{International Monetary Fund Washington, D.C.}




\section{INTERNATIONAL MONETARY FUND}

\section{PHILIPPINES}

\section{Selected Issues}

Prepared by Joji Ide, Shanaka J. Peiris, and Anita Tuladhar

Approved by Asia and Pacific Department

January 19, 2011

Contents

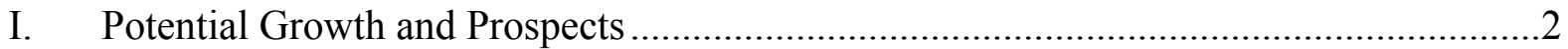

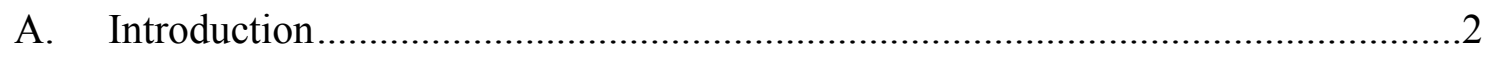

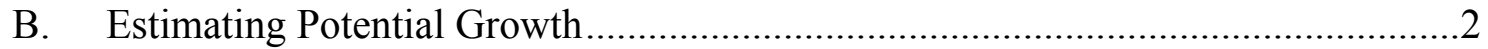

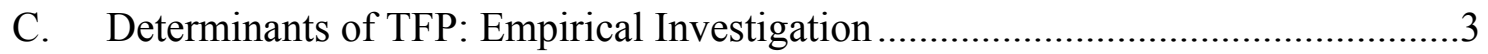

D. Investment and Employment: International Comparisons.......................................5

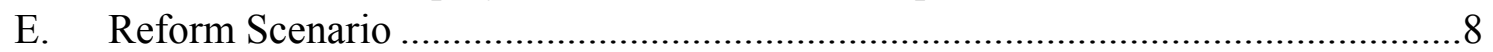

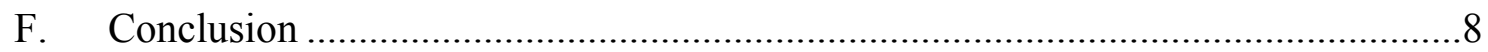

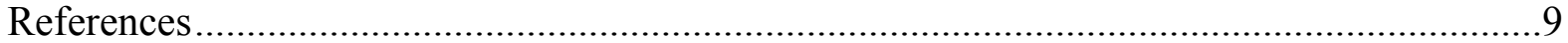

II. Forecasting and Monetary Policy Analysis System for the Philippines ..........................10

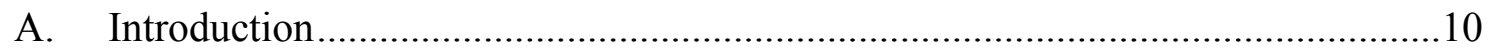

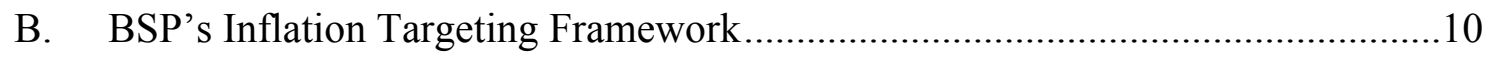

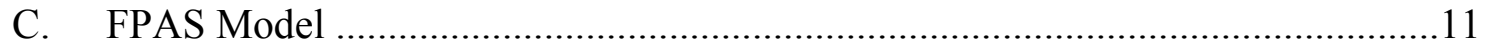

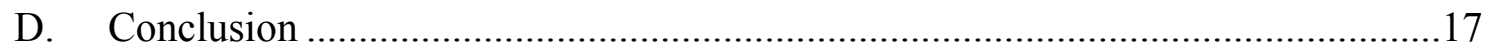

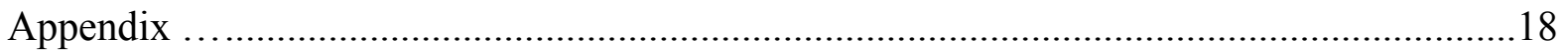

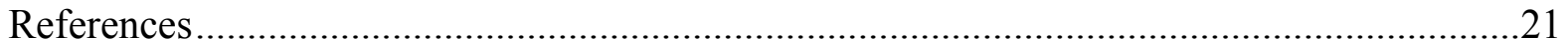

III. How will Fiscal Consolidation Affect Growth in the Philippines? ...............................22

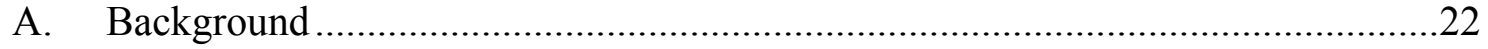

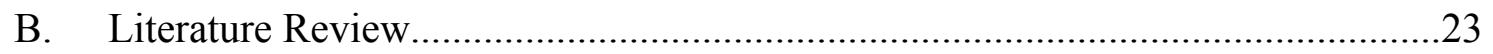

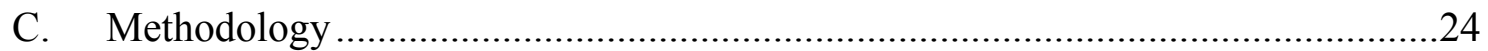

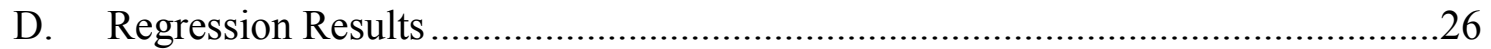

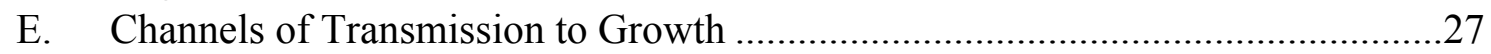

F. Fiscal Consolidation and Short-Run Growth.....................................................

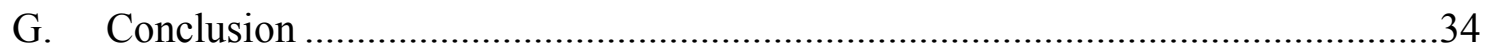

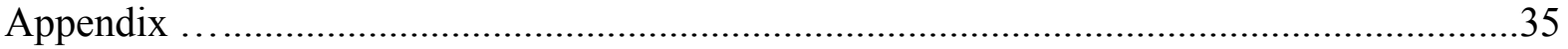

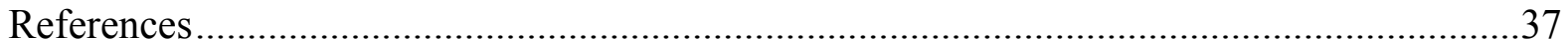




\section{Potential Growth and Prospects ${ }^{1}$}

\section{A. Introduction}

\section{This paper estimates potential growth in the Philippines using different} methodologies and discusses growth prospects for the medium term. Potential growth is a key input for assessing the supply capacity of the economy, which in turn has implications for assessments of macroeconomic policy. The production function approach highlights the scope for further increases in investment, employment, and total factor productivity (TFP). International comparisons and economic analysis, based on cross-country panel data, are used to shed light on the determinants of these growth pillars. The analysis highlights some areas in which measures may be particularly helpful for raising potential growth toward the authorities' $7-8$ percent target over the medium term.

\section{B. Estimating Potential Growth}

\section{Several approaches can be used to estimate potential growth. Some} methodologies rely on statistical techniques, while others are based on economic theory. In this paper for estimating potential growth in the Philippines, the following three approaches are used. A similar picture emerges from all three approaches, namely that potential growth in the Philippines has increased since the late 1990s. Potential growth was around 3-4 percent in the 1990s, but it increased in the 2000s and is now estimated to be around 5 percent.

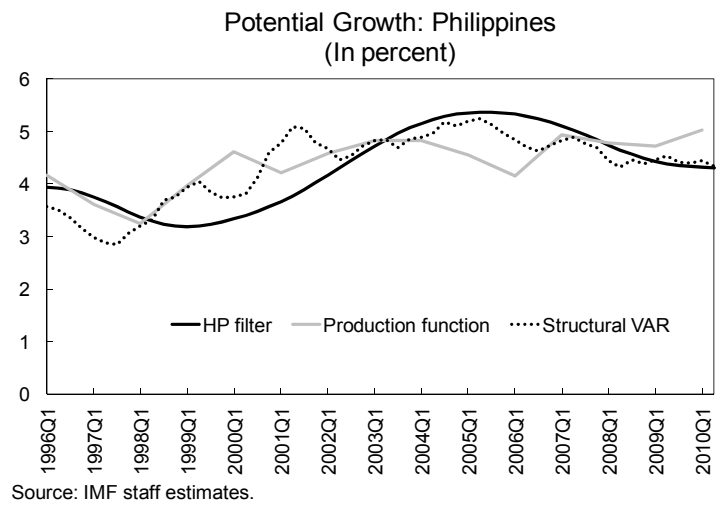

- $\quad$ Simple filtering approach. The Hodrick-Prescott (HP) approach is used as it is a common methodology that tries to decompose output into cycle and trend components. This approach is simple, as it requires only GDP as an input, but it suffers from the well-known "end-of-sample" problem and it also relies on a smoothing parameter that is chosen arbitrarily.

- $\quad$ Production function approach. A simple growth accounting framework based on a production function is used to decompose potential output into its components (labor, capital, and TFP). In this approach, potential growth is estimated as the weighted sum of growth in potential labor and capital inputs combined with trend growth in TFP, specified as follows:

\footnotetext{
${ }^{1}$ Prepared by Joji Ide (APD).
} 


$$
\Delta Y^{*}=\alpha \Delta L^{*}+(1-\alpha) \Delta K^{*}+\Delta T F P(\text { trend })
$$

where $Y^{*}$ is potential output, $L^{*}$ is potential labor input, $K^{*}$ is potential capital input, and $\alpha$ is labor's share of income. ${ }^{2}$ Although the approach also suffers from the same filtering problem as the HP approach, it has several strengths. One of the strengths is that it focuses explicitly on the supply capacity of the economy by using various data such as capital stock and employment. In addition, it allows analysts to identify the contributions of each of the sources of growth: labor, capital, and TFP.

- Multivariate time-series model approach. A bivariate vector autoregression (VAR) that includes quarterly data on output growth and unemployment rate is estimated by following the approach of Blanchard and Quah (1989). This approach allows the economic variables to determine the strengths of the relationship among them (Congressional Budget Office, 2004).

\section{Determinants of TFP: Empirical Investigation}

3. The production function approach indicates that the sources of growth have changed somewhat in the Philippines in line with other ASEAN economies. While the contribution of labor has been relatively stable, the contribution of TFP growth has increased since the 1990s and the contribution of capital has declined. The rising contribution of TFP and falling contribution of capital are features that the Philippines shares with its regional peers.
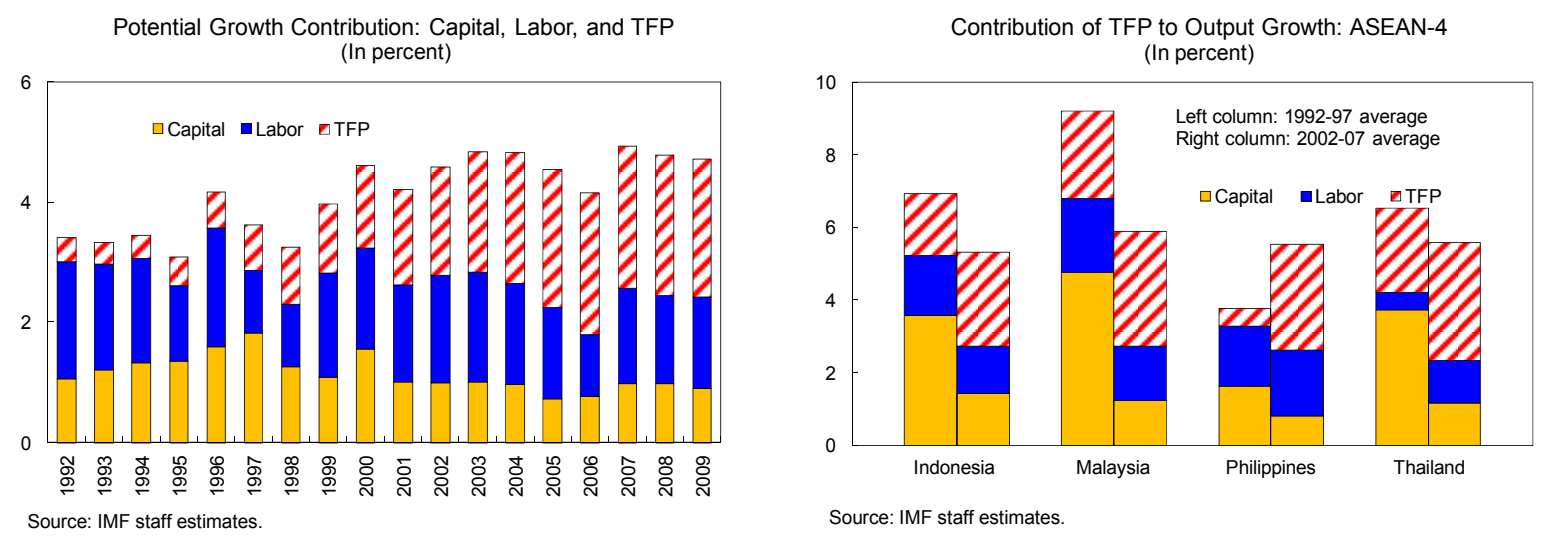

4. Understanding the drivers of TFP is important for analyzing economic growth as TFP plays an important role in sustaining long-term growth. Unlike the contributions

\footnotetext{
${ }^{2}$ Capital stock is estimated by the perpetual inventory method, which defines capital stock in each period as $K_{t}=(1-\delta) * K_{t-1}+I_{t}$ where $K t$ is capital stock in period $t, I t$ is investment during $t$, and $\delta$ is depreciate rate. Potential labor input is estimated by using data on population aged 15 years or over, labor force, employment, and mean hours worked.
} 
of factor inputs, such as population growth and capital accumulation, that are subject to diminishing returns, improvements in TFP can persist over the long term and can make a lasting contribution to growth.

5. Economic analysis based on cross-country panel regressions is employed to examine the determinants of TFP growth. The empirical literature on the determinants of TFP growth emphasizes the importance of trade openness, human capital, and institutional quality (Asian Development Bank, 2010). Jaumotte and Spatafora (2007) argue that initial employment in agriculture also can have a strong impact on TFP growth. In addition to these variables, the analysis in this section considers countries' initial level of per capita GDP and inflation, which are standard in the growth literature to capture the effects of convergence and macroeconomic stability (Barro, 1996, and Bosworth and Collins, 2003). Foreign direct investment is also included as an independent variable to capture the impact of technology diffusion. Accordingly, the regression equation is the following:

$$
\operatorname{TFP}_{i t}=c_{i}+\beta^{*} \operatorname{Ini}_{i t}+\sigma^{*} \operatorname{Inf}_{i t}+\gamma^{*} \operatorname{Open}_{i t}+\delta^{*} \operatorname{Gov}_{i t}+\rho^{*} \operatorname{Sch}_{i t}+\phi^{*} F D I_{i t}+\eta^{*} \operatorname{Sec}_{i t}+u_{i t}
$$

where Ini is real per capita GDP in the initial year of each period, Inf is inflation, Open is trade openness, Gov is institutional quality, $S c h$ is average secondary schooling years, $F D I$ is the ratio of FDI to GDP, Sec is the share of agriculture to GDP, $c$ is a constant term for each country, and $u$ is the error term. ${ }^{3}$ A panel dataset of 52 countries over the period 1981-2005 is used, and cross-country fixed effects panel regressions are employed. ${ }^{4}$

\section{The results suggest that higher institutional quality, better human capital, and a lower share of agriculture are correlated with TFP growth. ${ }^{5}$}

- Institutional quality: an improvement in the governance rating by 10 points is associated with a 0.3 percentage point increase in TFP growth.

\begin{tabular}{|c|c|c|c|}
\hline \multirow[b]{2}{*}{ Initial per capita GDP (In) } & \multicolumn{3}{|c|}{ TFP growth } \\
\hline & $\begin{array}{c}-3.98 \\
(-5.79)^{* * *}\end{array}$ & $\begin{array}{c}-4.05 \\
(-5.88)^{* \star \star}\end{array}$ & $\begin{array}{c}-4.76 \\
(-6.18)^{\star \star \star *}\end{array}$ \\
\hline Inflation rate (percent) & $\begin{array}{l}-0.001 \\
(-1.76)^{\star}\end{array}$ & $\begin{array}{l}-0.001 \\
(-1.67)^{\star}\end{array}$ & $\begin{array}{c}-0.001 \\
(-1.67)^{*}\end{array}$ \\
\hline Openness (percent of GDP) & $\begin{array}{c}0.02 \\
(1.87)^{*}\end{array}$ & $\begin{array}{c}0.02 \\
(2.03)^{* *}\end{array}$ & $\begin{array}{c}0.01 \\
(0.97)\end{array}$ \\
\hline Governance (rating) & $\begin{array}{c}0.05 \\
(3.26)^{* *}\end{array}$ & $\begin{array}{c}0.05 \\
(2.94)^{* *}\end{array}$ & $\begin{array}{c}0.03 \\
(1.98)^{* *}\end{array}$ \\
\hline Secondary schooling year (year) & $\begin{array}{c}1.07 \\
(3.07)^{* *}\end{array}$ & $\begin{array}{c}0.97 \\
(2.78)^{* *}\end{array}$ & $\begin{array}{c}0.77 \\
(2.20)^{* *}\end{array}$ \\
\hline Foreign direct investment (percent of GDP) & $\begin{array}{l}\ldots \\
\ldots\end{array}$ & $\begin{array}{l}0.08 \\
1.54\end{array}$ & $\begin{array}{c}0.09 \\
(1.76)^{*}\end{array}$ \\
\hline Agriculture sector share (percent of GDP) & $\ldots$ & $\ldots$ & $\begin{array}{c}-0.14 \\
(-2.50)^{* *}\end{array}$ \\
\hline Number of observations & 255 & 251 & 245 \\
\hline Adj. $R^{2}$ & 0.35 & 0.36 & 0.37 \\
\hline
\end{tabular}

\footnotetext{
${ }^{3}$ The index of governance that reflects perceptions of corruption is used as a proxy to measure institutional quality. The index is compiled by the International Country Risk Guide. The share of agriculture value added to GDP from the World Development Indicators is used as a proxy to measure the transition of economic activity from agriculture to industry and services.

${ }^{4}$ Non-overlapping five-year averages are used. The sample mainly consists of emerging and developing economies, but some advanced economies such as Korea are included. Time specific effects are not captured in this analysis. In terms of the individual country effects, the use of a fixed effects rather than a random effects model is justified by the Hausman test.

${ }^{5}$ In addition, all variables have expected signs.
} 
- Human capital: a one year increase in average secondary schooling years is associated with a 0.8 percentage point increase in TFP growth.

- $\quad$ Share of agriculture in GDP: a reduction in this share by 5 percentage points (comparable to change during 1996-2005 in the Philippines) is associated with a 0.7 percentage point increase in TFP growth.

\section{Investment and Employment: International Comparisons}

7. International comparisons regarding investment suggest that addressing the low level of investment in the Philippines would be critical for raising potential growth over the medium term. Both public and private investments have been anemic in the Philippines compared with other Asian economies. The ratio of public and private investment to GDP declined from 5 percent in the 1990s to 3 percent in the 2000s and from 17 percent to 13 percent during the same period, respectively. Although it is difficult to estimate individual countries' optimal level of investment, given differences in economic structure, the capitalto-output and investment-to-output ratios in the Philippines are low relative to steady-state levels in 2008 (IMF, 2010a).
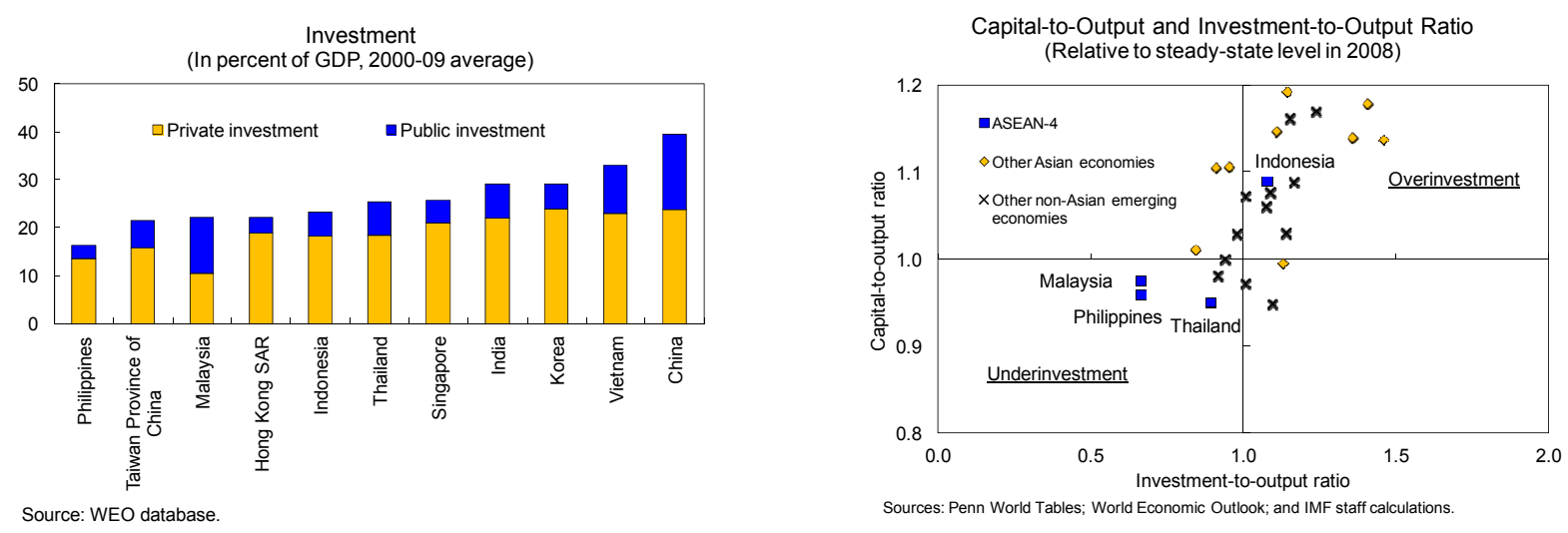

8. Fiscal slippages and difficulties in the business climate in the past may have contributed to the relatively low level of investment. Cross-country comparisons suggest that there is a clear link between the revenue-to-GDP ratio and the public investment rate. The level of public investment has been low in the Philippines, owing to low public revenue, and the debt service burden has been high relative to other Asian economies. In this context, reversing revenue slippages would be critical to raise public investment over the medium term. Another important reason for low investment seems to be the business environment. ${ }^{6}$

\footnotetext{
${ }^{6}$ The relatively high share of the services sector may also explain the low level of investment in the Philippines. In fact, the share of the services sector has been higher than that in other ASEAN economies and increased from 47 percent in the 1990s to 54 percent in the 2000s. Bocchi (2008) points out that the growing businesses in the services sector such as the business process outsourcing (BPO) sector are less capital intensive than the industrial sector. However, the literature on the determinants on investment is inconclusive about the relationship between private investment and the shares of the industrial and services sectors (IMF, 2010b).
} 
The World Bank Doing Business 2010 suggests that the business environment in the Philippines continues to lag behind those in other Asian economies, particularly in terms of starting a business and protecting investors. Reducing the costs of doing business by streamlining business procedures and improving governance by tackling corruption and strengthening the legal system would be helpful to raise private investment.
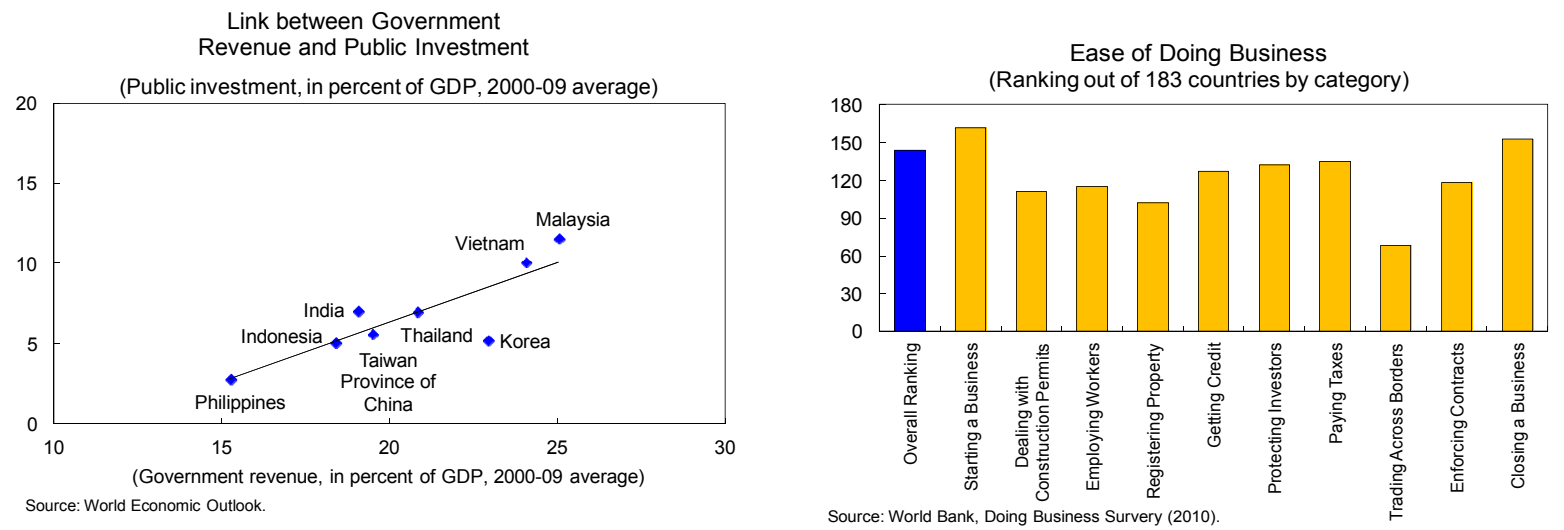

\section{Although basic infrastructure in the Philippines has improved somewhat over} the years, it continues to lag behind regional comparators in several dimensions. For instance, the Philippines still lags with respect to electricity generation, telephone lines, and paved roads. The lags in infrastructure owe in part to low public investment. In this context, the authorities' intentions to rely more on public private partnerships (PPPs) in order to develop infrastructure could be helpful. As several studies suggest, improvements in basic infrastructure can have a positive spillover effect on private investment (IMF, 2010b).
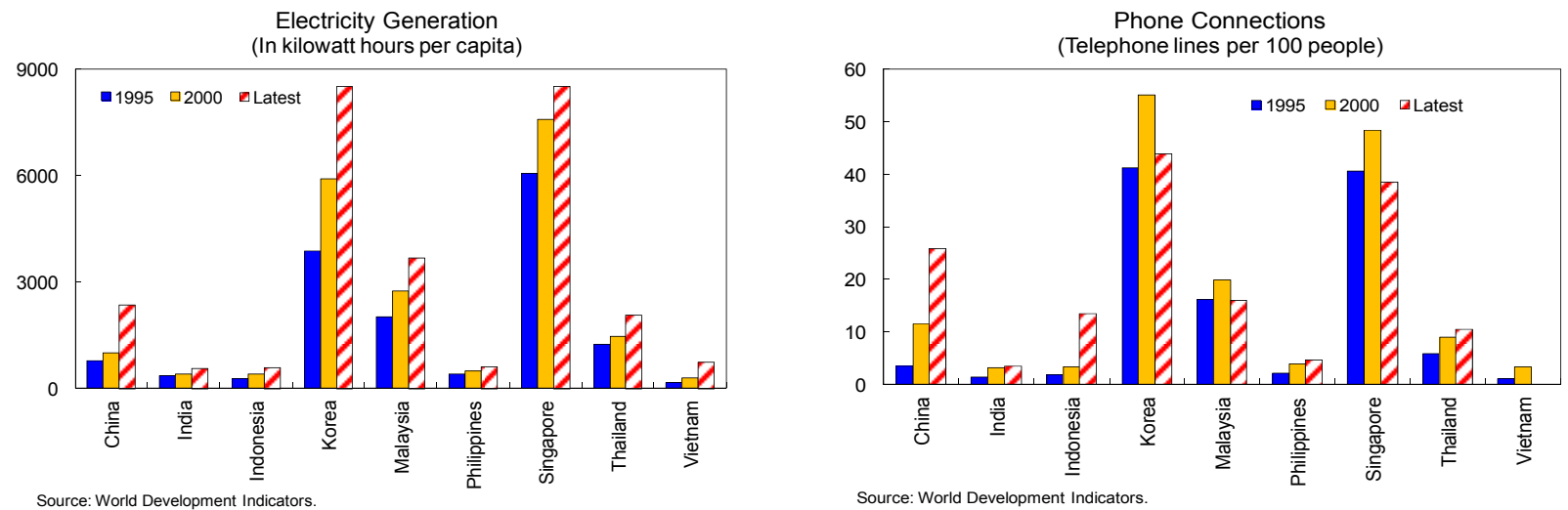


\section{The high level of unemployment remains a challenge in the Philippines.}

Employment in the Philippines grew by nearly 40 percent from 1995 to 2009, and the pace of growth has been faster than other ASEAN-4 economies with the exception of Malaysia.

Employment growth has not, however, been strong enough to reduce the unemployment rate substantially, partly due to the rapid increase in the labor force. The unemployment rate has been around 7-8 percent in recent years and remains high in comparison with other ASEAN economies. The underemployment rate also remains high at around 18 percent. $^{7}$
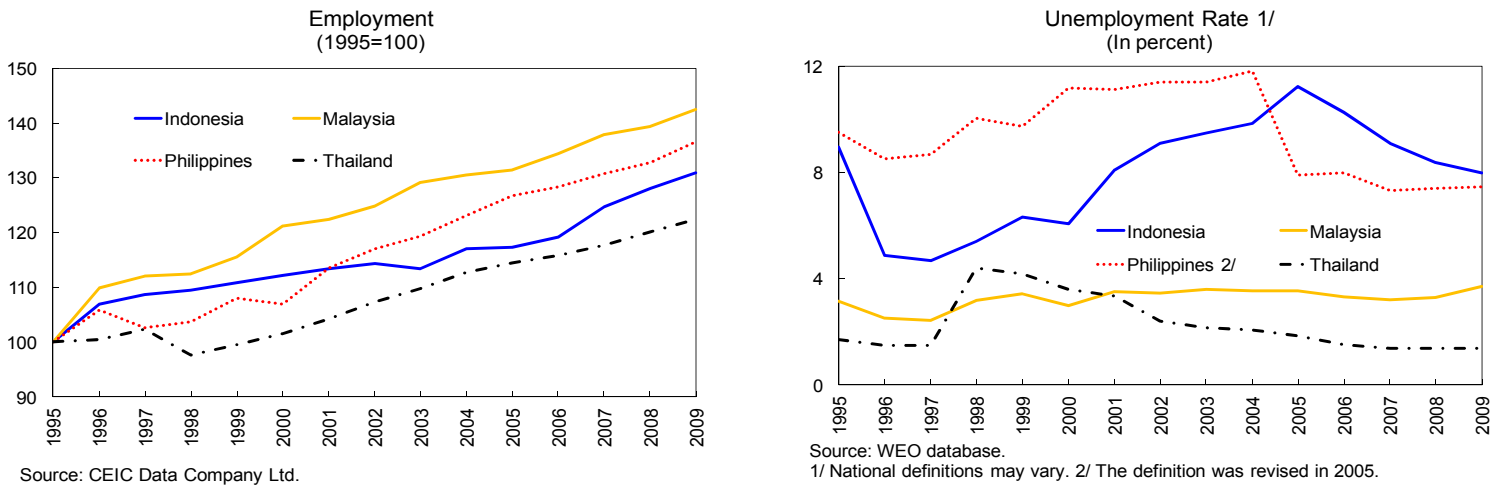

11. The relationship between output growth and the unemployment rate appears relatively weak in the Philippines. Okun's law captures the relationship between these two variables, and the correlation has been historically weaker in the Philippines than in Malaysia or Thailand. The weak relationship suggests that there may be some structural issues in the Philippine labor market. One such issue could be the high proportion of self-employed workers and unpaid family workers, who account for around 40 percent of total employment. In addition, redundancy costs in the Philippines are relatively high, and hiring and firing practices are relatively heavily regulated (World Economic Forum, Global Competitiveness Report 2010-11). In this context, promoting labor market flexibility would be helpful to improve labor market efficiency. In addition, active labor market measures such as job training and search assistance, remedial education, and job creation targeted at helping younger people may be helpful to reduce mismatches in the labor market as well as to increase employment and raise its quality (Asian Development Bank, 2008).

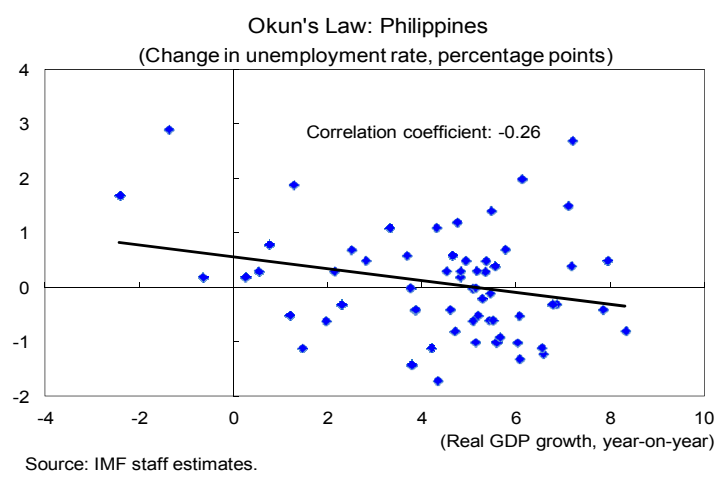

\footnotetext{
${ }^{7}$ Employed persons who express the desire to have additional work in their present job, to have an additional job, or to have a new job with longer working hours are considered underemployed.
} 


\section{E. Reform Scenario}

12. All three pillars of growth need to be strengthened to raise potential growth over the medium term. An illustrative reform scenario that would see potential growth rise to the authorities' target of 7-8 percent could include the following elements.

- $\quad \boldsymbol{T F P}$. Continued investment in human capital, improving institutional quality by tackling corruption, and moving up the value chain from agriculture into industry and services would be important. Based on the regression results, an increase in average secondary schooling years by 0.3 years, an improvement in the governance index rating by 7 points, and a further transition of economic activity from agriculture to industry and services by 3 percentage points could raise the growth contribution of TFP from 2 percent historically to 3 percent by 2015 .

- Investment. Fiscal reforms and improvements in the business climate that raise the investment rate from its historical average of 15 percent of GDP to $191 / 2$ percent by 2015 could raise the growth contribution of capital from 1 percent historically to 2 percent by 2015 .

Growth Contribution Under a Reform Scenario

\begin{tabular}{ccc}
\hline & $\begin{array}{c}2000-09 \\
\text { (average) }\end{array}$ & $\begin{array}{c}2015 \\
\text { (reform) }\end{array}$ \\
\hline Potential growth (percent) & 4.6 & 7.0 \\
Contribution of TFP (percent) & 2.0 & 3.0 \\
Contribution of capital (percent) & 1.0 & 2.0 \\
Contribution of labor (percent) & 1.6 & 2.0 \\
\hline Source: IMF staff estimates. & &
\end{tabular}

- Employment. Continued growth in the industrial and services sectors would be needed for creating jobs over the medium term. Improvements in labor market flexibility and active labor market measures such as job training and search assistance would also be helpful to increase employment and raise the contribution of labor from historical averages.

\section{F. Conclusion}

\section{This chapter provides estimates of potential growth in the Philippines and} highlights the scope for raising growth potential over the medium term. Estimations based on different methodologies show that potential growth has risen to around 5 percent in recent years. Going forward, potential growth could be raised further toward the authorities' 7-8 percent target by strengthening all three pillars of growth. In particular, international comparisons suggest that rebalancing growth by relying more on investment will be critical. Addressing the low level of investment will require reversing revenue slippages and improving the business climate and basic infrastructure. Raising investment will also help to create more job opportunities and will keep step with structural reforms such as improving institutional quality and moving up the value chain from agriculture into industry and services in order to boost TFP growth further. 


\section{REFERENCES}

Asian Development Bank, 2008, Asian Development Outlook 2008 (Manila).

Asian Development Bank, 2010, Asian Development Outlook 2010 Update (Manila).

Barro, Robert J., 1996, "Determinants of Economic Growth: A Cross-Country Empirical Study,” NBER Working Paper No. 5698 (Washington).

Blanchard, O., and D. Quah, 1989, "The Dynamic Effects of Aggregate Demand and Supply Disturbances," The American Economic Review, Vol. 79, No. 4, pp. 655-673.

Bocchi, A., 2008, "Rising Growth, Declining Investment: The Puzzle of the Philippines," World Bank Policy Research Working Paper No. 4472 (Washington).

Bosworth, Barry, and Susan M. Collins, 2003, "The Empirics of Growth: An Update," Brookings Papers on Economic Activity, Vol. 2003, No. 2.

Congressional Budget Office, 2004, “A Summary of Alternative Methods for Estimating Potential GDP," (Washington).

International Monetary Fund, 2010a, Regional Economic Outlook: Asia and Pacific, April 2010 (Washington).

International Monetary Fund, 2010b, Regional Economic Outlook: Asia and Pacific, October 2010 (Washington).

Jaumotte F., and N. Spatafora, 2007, “Asia Rising: A Sectoral Perspective,” IMF Working Paper No. 07/130 (Washington).

World Bank, 2010, “Doing Business 2010” (Washington).

World Economic Forum, 2010, “Global Competitiveness Report 2010-2011” (Geneva, Switzerland). 


\section{Forecasting And Monetary Policy Analysis System for the Philippines ${ }^{1}$}

\section{A. Introduction}

\section{This chapter estimates a forecasting and monetary policy analysis system}

(FPAS) model for the Philippines. The appropriate monetary policy stance depends on inflation forecasts (and expectations), the distribution of exogenous shocks affecting the economy, and the monetary transmission mechanism. The Global Financial Crisis highlighted the importance of taking into account both domestic and global shocks (and uncertainty) as well as macro-financial transmission mechanisms in the design of monetary policy in emerging markets. An FPAS model that incorporates such elements can provide a systematic framework to consider policy trade-offs under an inflation forecast targeting (IFT) regime (see Laxton, and others, 2009).

2. In the Philippines, with the output gap closing in 2010 in light of the rapid economic recovery, and real policy rates significantly below pre-crisis levels, the monetary stance is assessed to be accommodative. An inflation forecast conditional on the WEO forecast for the U.S. economy, global oil prices, and estimated distributions for stochastic shocks in the Philippines suggests that the monetary stance may need to be tightened in the near term for inflation to remain within the Bangko Sentral ng Pilipinas's (BSP) target range over the policy horizon.

\section{B. BSP's Inflation Targeting Framework}

\section{The Philippines' shift to an IFT regime in $\mathbf{2 0 0 2}$ has so far yielded low and stable}

inflation. The national government, through the Development Budget Coordinating Committee (DBCC), sets the inflation target based on the headline consumer price index (CPI) two years ahead in consultation with the BSP. The BSP has full powers over and responsibility for the announcement of the inflation target and the determination of appropriate monetary policy to achieve the target. The target was generally achieved during 2002-07, with average inflation very close to the midpoint average of the target. In early 2008, the extraordinary increase in global commodity prices influenced inflation developments and was closely followed by the global crisis. ${ }^{2}$

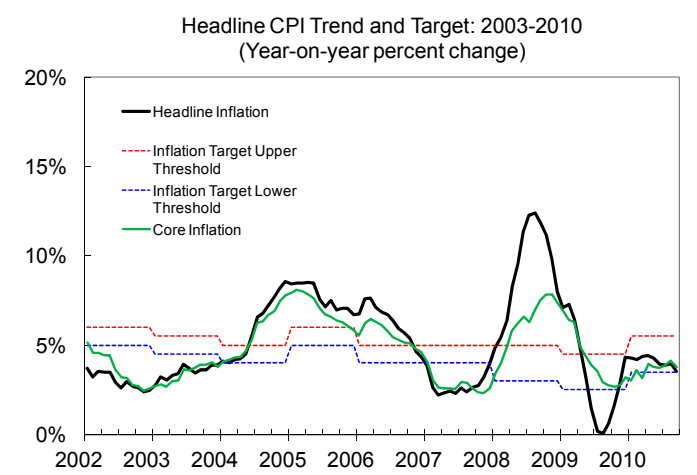

\footnotetext{
${ }^{1}$ Prepared by Shanaka J. Peiris (APD).

2 The BSP's monetary policy framework provides for exemption clauses to recognize the fact that there are limits to the effectiveness of monetary policy and that there may be occasional breaches owing to factors beyond the control of the central bank (see Guinigundo, 2010).
} 
4. The inflation forecast is a major factor considered by the BSP when deciding whether monetary policy instruments should be adjusted to attain the inflation target. ${ }^{3}$ The government's targets for annual headline inflation have been set at 4.0 percent for 2011 and 2012 with a tolerance interval of \pm 1.0 percentage point (BSP, 2010). In July 2010, the BSP extended through 2014 the 3-5 percent inflation target to help anchor medium-term inflation expectations. According to the BSP, baseline inflation forecasts are generated from the BSP's single equation model and the multi-equation model. ${ }^{4}$ The FPAS model estimated below could be viewed as a complementary approach to those econometric approaches.

\section{FPAS Model}

5. The monetary policy analysis is conducted by extending to better capture Philippine specific factors the small "New Keynesian" macroeconomic model of Berg, Karam, and Laxton (2006a). ${ }^{\mathbf{5}}$ The FPAS model is a stripped down version of a stochastic general equilibrium (DSGE) model with rational expectations. In recent years, the macroeconomic literature has used DSGE models and small New Keynesian models to analyze economic behavior and to forecast future developments. The DSGE models are based on theoretical underpinnings and have been found to be useful for analyzing the effects of structural changes in the economy, as well as the effects of longer-term developments such as persistent fiscal and current account deficits. On the other hand, by virtue of their relatively simple structure, small New Keynesian models have been used for forecasting and policy analysis purposes in central banks and by IMF country desks. A number of inflation-targeting central banks have used similar models as an integral part of their FPAS (see Laxton and others, 2009).

6. To capture the commodity dependence and importance of the banking system in the Philippines, the baseline model is extended to incorporate oil prices and macrofinancial linkages through a credit conditions variable (Carabenciov and others, 2008). In addition, fiscal shocks are introduced to the FPAS model as in Honjo and Hunt (2006). The model features a small open economy including forward-looking aggregate supply and demand with microfoundations and with stylized (realistic) lags in the different monetary transmission channels. External shocks from the rest of the world are captured here by U.S. growth. Output developments in the rest of the world feed directly into the small economy as they influence foreign demand for Philippine products. Changes in foreign inflation and

\footnotetext{
3 In conveying to the public the views of the BSP, an assessment of the output gap is presented along with the inflation forecast. The BSP also assesses inflation expectations, evidence of second-round effects, and the yield curve among a host of critical factors (see Guinigundo, 2010).

${ }^{4}$ See McNelis and Bagsic, (2007) for details on the BSP inflation forecasting models and performance.

${ }^{5}$ This contrast with the financial programming approach, which emphasizes the role of monetary aggregates in analyzing the monetary sector (see Berg, Karam, and Laxton, 2006, for a discussion of the different approaches).
} 
interest rates affect the exchange rate and, subsequently, demand and inflation in the Philippines (Figure 1).

Figure 1. The Monetary Policy Transmission Mechanism

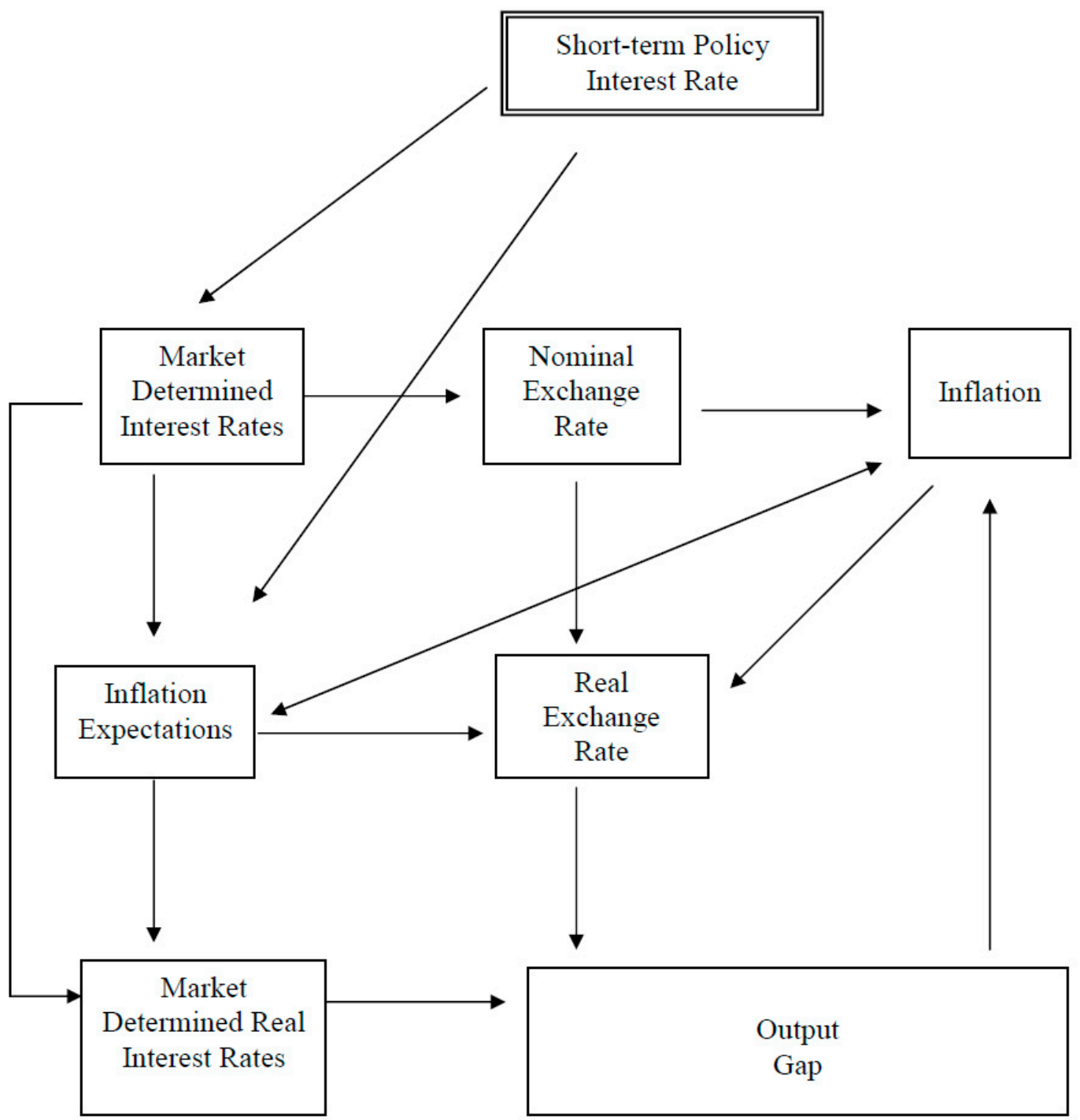

7. The model is estimated using Bayesian techniques based on prior distributions for the parameters from cross-country work and assumptions about the Philippine economy. Bayesian estimation in a situation of a relatively small sample size (which is almost always the case for macro time series data) helps ameliorate the problems of classical econometric estimation, which often gives macro model results that are inconsistent and faced with simultaneity challenges. This is a particularly important aspect for the Philippines where there was a structural change in 2002 when BSP switched to an IFT framework, necessitating a sub-sample estimation from 2002 to 2010 to confirm the robustness of the full sample estimates. The model is estimated based on quarterly data from 1996 to 2010 using prior empirical knowledge about the parameters of interest for the Philippines or cross- 
country studies on emerging markets. All variables are seasonally adjusted using the X12 filter, with the exception of the interest rate and the exchange rate, and expressed in "gap" terms, defined as deviations from a Hodrick-Prescott time trend.

\section{The parameter estimates shed new insight into the monetary transmission} mechanism in the Philippines, the role of domestic and global shocks, and the weights placed on inflation, the output gap, and the exchange rate in an open-economy Taylorrule. The model has four behavioral equations: (1) an aggregate demand or IS curve that relates the level of real activity to expected and past real activity, the real interest rate, the real exchange rate, foreign demand, the fiscal stance, and financial conditions; (2) a price setting or Phillips curve that relates inflation to past and expected inflation, the output gap, fuel prices, and the exchange rate; (3) an uncovered interest parity condition for the exchange rate, with some allowance for backward looking expectations; and (4) an open-economy Taylor-rule for setting the policy interest rate as a function of the output gap, expected inflation, and the exchange rate.

(1) The aggregate demand equation and results are as follows:

$$
\begin{aligned}
& \operatorname{ygap}_{t}=\beta_{\text {ld }} \text { ygap }_{t+1}+\beta_{\text {lag }} \text { ygap }_{t-1}-\beta_{\text {RRgap }} \text { RRgap }_{t-1}+\beta_{\text {Zgap }} \text { zgap }_{t-1}+\beta_{R W y g a p} \text { ygap }_{t}^{R W} \\
& -\beta_{\text {FBgap }} \text { FBgap }_{t-1}+\beta_{B L} \eta_{t}+\varepsilon_{t}^{\text {ygap }}
\end{aligned}
$$

where ygap is the output gap, RRgap the real interest rate gap, zgap the real exchange rate gap, $y g a p^{R W}$ the output gap in the United States, FBgap the fiscal gap, $\eta$ lending conditions based on the ratio of bank credit to GDP, $\beta$ a series of parameters attached to these variables, and $\varepsilon^{\text {ygap }}$ an error term that captures other temporary exogenous demand shocks. (An extension of the model to include fiscal and lending conditions is detailed in Appendix 1).

- $\quad$ Berg, Karam, and Laxton (2006b) suggest that the value of $\beta_{\text {lag }}$ will lie between 0.5 and 0.9 , with a lower value for less advanced economies more susceptible to volatility. The coefficient of 0.68 for $\beta_{\text {lag }}$ is comparable to other emerging markets.

\begin{tabular}{llll} 
The lead of the output gap $\left(\beta_{l d}\right)$ is typically small, & Parameter & Prior & Posterior \\
\cline { 3 - 5 } between 0.05 and 0.15 , and the estimated value for & $\beta_{\text {lag }}$ & 0.65 & 0.68 \\
the Philippines is at the midpoint of that range. The & $\beta_{l d}$ & 0.1 & 0.11 \\
parameter $\beta_{\text {RRgap }}$ indicates the effectiveness of the & $\beta_{\text {RRgap }}$ & 0.1 & 0.04 \\
monetary transmission mechanism, while $\beta_{\text {zgap }}$ and & $\beta_{\text {Zgap }}$ & 0.05 & 0.02 \\
$\beta_{\text {RWgap }}$ depend on the importance of the exchange & $\beta_{\text {RWgap }}$ & 0.15 & 0.14 \\
rate channel and the degree of openness. The & $\beta_{F B g a p}$ & 0.2 & 0.21 \\
\cline { 4 - 5 } & $\theta_{B L}$ & 0.1 & 0.12 \\
\hline
\end{tabular}
posterior estimates of $\beta_{\text {RRgap }}$ and $\beta_{\text {zgap }}$ suggest that the interest rate effect on aggregate demand is stronger than the exchange rate effect 
possibly reflecting the importance of factors beyond the exchange rate for competitiveness (e.g., costs of doing business). The value for $\beta_{\text {RWygap }}$ is high, as would be expected given the Philippines' non-diversified export dependence. The fiscal gap and bank lending conditions have the expected negative and positive impact, respectively, on aggregate demand. The former highlights a potential role for counter-cyclical fiscal policy and the latter the importance of a credit channel and financial accelerator effects.

\section{(2) The Philips curve equation and results are as follows:}

$$
\pi_{t}=\alpha_{\text {Idd }} \pi 4_{t+1}+\left(1-\alpha_{\text {ddd }}\right) \pi 4_{t-1}+\alpha_{\text {ygap }} y g a p_{t-1}+\alpha_{z g a p}\left(z_{t}-z_{t-1}\right)+\alpha_{o}\left(\pi_{t}^{o}-\pi^{o}\right)+\alpha_{\text {olag }}\left(\pi_{t-1}^{o}-\pi^{o}\right)+\varepsilon_{t}^{\pi}
$$

where $\pi 4_{t+1}$ is the four-quarter ahead inflation rate (year/year), $\pi_{t} 4_{t-1}$ the four-quarter lagged inflation rate, ygap the output gap, $z_{t}-z_{t-1}$ the real depreciation, $\alpha$ the parameters, $\pi_{t}^{o}$ domestic fuel price inflation, and $\varepsilon_{t}^{\pi}$ an error term.

- $\quad$ The $\alpha_{\text {sld }}$ parameter in the headline inflation equation determines the forward-looking component of inflation (while its inverse 1 $\alpha_{\text {tdd }}$ determines the backward-looking component). The parameter value can be interpreted as depending in part on the

\begin{tabular}{lcc}
\hline Parameter & Prior & Posterior \\
\hline$\alpha_{\text {Ild }}$ & 0.50 & 0.61 \\
$\alpha_{\text {ygap }}$ & 0.40 & 0.45 \\
$\alpha_{\text {zgap }}$ & 0.05 & 0.01 \\
$\alpha_{o}$ & 0.01 & 0.02 \\
$\alpha_{\text {olag }}$ & 0.01 & 0.03 \\
\hline
\end{tabular}
credibility of the central bank and in part on institutional arrangements regarding wage indexation and other price-setting mechanisms. A high value of $\alpha_{\text {Ild }}$, close to 1 , would suggest that small changes in monetary policy cause large changes in price expectations. The $\alpha_{\text {ygap }}$ parameter depends on the extent to which output responds to price changes and, conversely, how much inflation is influenced by real demand pressures, and is typically between $0.25-0.50$. This parameter ultimately depends on the "sacrifice ratio" (the loss of output necessary to bring down inflation) and is estimated to be relatively high in the Philippines at 0.45 . The $\alpha_{\text {zgap }}$ parameter represents the short-term pass-through of (real) exchange rate movements into prices, and depends on trade openness, price competition, and monetary policy credibility. The exchange rate pass-through coefficient is estimated to be relatively low in the Philippines taking into account other factors such as global oil prices, which feed into higher inflation with a short lag.

\section{(3) The uncovered interest parity equation and results are as follows:}

$$
z_{t}=\delta_{z} z_{t+1}+\left(1-\delta_{z}\right) z_{t-1}-\left[R R_{t}-R R_{t}^{R W}-\rho^{*}\right] / 4+\varepsilon_{t}^{z}
$$


where $z_{t}$ is the real exchange rate (an increase represents a depreciation), $R R_{t}$ the real interest rate, $R R_{t}^{R W}$ the U.S. real interest rate, $\rho^{*}$ the historical average risk premium on the domestic currency, $\delta_{z}$ the smoothness parameter, and $\varepsilon_{t}^{z}$ an error term. This equation, an uncovered interest rate parity condition, posits that the real exchange rate is a function of the expected real exchange rate (the first two terms), the real interest rate differential (the currency risk premium), and a disturbance term.

- The $\delta$ parameter in the real exchange rate equation determines the relative importance of forward- and backward-looking real exchange rate expectations. If $\delta$ is equal to 1 , the exchange rate behaves as in the Dornbusch overshooting

\begin{tabular}{lcc}
\hline Parameter & Prior & Posterior \\
\hline$\delta_{z}$ & 0.4 & 0.75 \\
\hline
\end{tabular}
model (the real exchange rate is a function of the future sum of all real interest rate differentials). The estimated coefficient of 0.75 makes monetary policy potentially a more effective tool, though the low exchange rate pass-through in the Philippines somewhat reduces its efficacy.

(4) The open-economy Taylor-rule and results are as follows:

$$
R S_{t}=\gamma_{R S l a g} R S_{t-1}+\left(1-\gamma_{R S l a g}\right) *\left(R R_{t}^{*}+\pi 4_{t}+\gamma_{\pi}\left\lfloor\pi 4_{t+4}-\pi_{t+4}^{*}\right\rfloor+\gamma_{\text {ygap }} \text { ygap }_{t}+\gamma_{\text {zgap }} \text { zgap }_{t}\right)+\varepsilon_{t}^{R S}
$$

- $\quad$ The $\gamma$ parameters in the monetary policy rule equation depend on the speed and extent to which the monetary authorities adjust the nominal interest rate, and the relative

\begin{tabular}{lcc}
\hline Parameter & Prior & Posterior \\
\hline$\gamma_{\text {RSlag }}$ & 0.75 & 0.91 \\
$\gamma_{\pi}$ & 1.10 & 2.20 \\
$\gamma_{\text {ygap }}$ & 0.50 & 0.51 \\
$\gamma_{\text {zgap }}$ & 0.10 & 0.35 \\
\hline
\end{tabular}
activity target. There is a high degree of interest smoothing in the Philippines but the BSP does aggressively respond to inflation forecasts (expectations) above the targeted level. It is common for central banks to pay some attention to real activity even in a "pure" inflation targeting framework and, thus, for the $\gamma_{\text {ygap }}$ coefficient to be greater than zero. We choose a value of 0.5 as a prior, in line with other countries. This is borne out in the Philippines where the weight on real activity is comparable to other emerging markets. $\gamma_{\text {zgap }}$ reflects the weight on the real exchange rate, which has been observed to be quite significant in emerging markets (see Stone and others, 2009). The estimated coefficient indicates that the BSP appears to place some weight on exchange rate developments in conducting monetary policy, although the coefficient is less than many other emerging markets.

9. The impact of global demand shocks on the economy is significant. As far as the impulse response functions are concerned (Appendix Figures 1-3), the model shows reasonable and expected patterns. Global demand shocks have a significant impact on output and inflation dynamics, requiring a monetary policy response to help stabilize the economy. Domestic demand shocks also have a large impact on aggregate demand and inflation developments. 
10. The variance decomposition of all stochastic shocks suggests that demand and supply shocks are nearly equally important in accounting for inflation dynamics. This equality contrasts somewhat with the perceived dominance of supply-side factors in Asia among many policy-makers and results of pure empirical vector-autoregression (VAR) based studies, highlighting the need for more systematic and country-specific analyses to better identify and interpret shocks.

\section{Using the estimated parameters and distributions for the stochastic shocks,} solutions are derived for the variability in inflation and the output gap under alternative monetary policy reaction functions. First, simulations of the FPAS model search for the "optimal" values for the coefficients of the Taylor rule by minimizing a loss function of inflation and output variability. The loss function takes the form of a standard quadratic form given by:

$$
L=\sum_{t=0}^{\infty} \lambda_{\pi}\left(\pi_{t}-\pi^{T}\right)^{2}+\lambda_{y}\left(\text { ygap }_{t}\right)^{2}
$$

where $\lambda_{\pi}$ and $\lambda_{y}$ are the relative weights on inflation and output-gap variability and $\pi^{T}$ is the inflation target. For simplicity, the weights are assumed to be equal. Second, the analysis compares the standard deviation of inflation and the output gap of the estimated model with one with the "optimal" coefficients of the Taylor rule given the same size and types of shocks faced by the economy. The simulations suggest that a greater weight on inflation and a smaller weight on output and the exchange rate would help to reduce macroeconomic volatility (text table).

\begin{tabular}{lcc}
\hline & Estimated & Optimal \\
\hline$\gamma_{\text {RSlag }}$ & 0.91 & 0.81 \\
$\gamma_{\pi}$ & 2.20 & 3.50 \\
$\gamma_{\text {ygap }}$ & 0.50 & 0.45 \\
$\gamma_{\text {zgap }}$ & 0.35 & 0.28 \\
\hline
\end{tabular}

\section{The model-based forecast suggests that in order for inflation to remain within} the BSP's target range, the monetary stance would need to be tightened over the next two years. The analysis forecasts inflation and other real economy factors (such as the output gap) conditional on the WEO forecast for the U.S. economy, global oil prices, and estimated distributions for stochastic shocks including supply-side factors in the Philippines. ${ }^{6}$ The simulations based on the estimated Taylor-rule suggest that over the next two years the BSP would have to unwind the monetary easing that it put in place during the crisis in order to keep headline inflation within the 3-5 percent target range (text figure).

\footnotetext{
${ }^{6}$ The model-based forecast provides a relatively good out-of-sample forecast (compared to a bayesian VAR beyond two lags).
} 


\section{Inflation Forecast: 2010Q3-2012Q4 \\ (Quarter/Quarter) \\ Conditional on WEO assumptions}

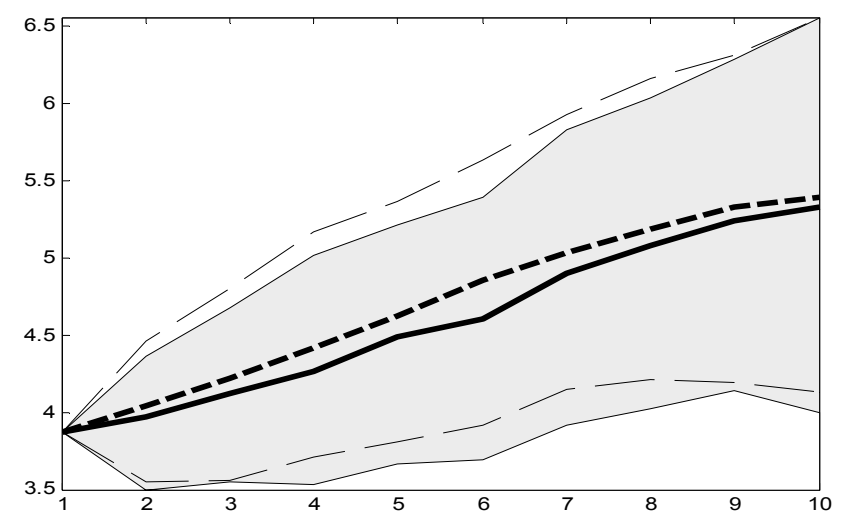

Note: Thick line is the forecast conditional on the WEO assumptions.

The shaded area is the $80^{\text {th }}$ percentile of the forecast distribution. Dotted line is the unconditional forecast.

\section{Conclusion}

13. The forecasting and monetary policy analysis model of the Philippine economy presented in this chapter could be helpful to guide monetary policy decisions. The model estimates shed light on the monetary transmission mechanism and impact of domestic and global shocks. The out-of-sample forecast performance of the model is good. The model could also be used for risk-assessments of the baseline inflation forecast and counter-factual scenarios conditional on the global economic outlook and alternative policy reactions functions. Preliminary simulations suggest that the appropriate response of the BSP to keep inflation within target range would be to roughly unwind its crisis-related monetary easing over the next two years. Philippines' susceptibility to global demand conditions also suggests that the timing of the monetary normalization could be recalibrated in the event of renewed global turmoil.

\section{Further work could extend the FPAS model for the Philippines in a number of}

directions. First, the impact of shocks to potential output could be explicitly accounted for, rather than implicitly gauged through shocks to the output gap. Second, the implications of food prices for "core" inflation and inflation expectations could be further explored, given the large weight of food in the Philippines consumer price index. Finally, the recent surge in capital inflows to the Philippines could warrant a more explicit modeling of their role, possibly in a full-DSGE model. 


\section{APPENDiX}

This chapter extends the workhorse model of Berg, Karam, and Laxton (2006b) to better capture Philippine-specific factors:

- $\quad$ First, the large and persistent fiscal deficit in the Philippines could be an important source of shocks to the economy. Therefore, we include the fiscal gap in the output gap equation and a fiscal rule to simultaneously capture the possibility of countercyclical fiscal policy and ensure a stable public debt, as in Honjo and Hunt (2006). The specification is:

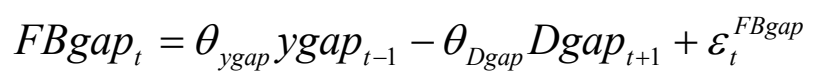

where $F B$ is the fiscal balance gap, and Dgap the deviation from the government's debt target. The foreign sector does not have an endogenous fiscal policy reaction function. Debt is defined as the cumulative fiscal balance, and the debt target is set equal to zero, which implies the equilibrium fiscal balance is zero and there is no debt accumulation over time. This can be thought of as normalization around a nonzero, but constant, ratio of public debt to GDP.

- $\quad$ Second, this chapter extends the model to include macro-financial linkages as in Carabenciov and others (2008). The global financial crisis and great recession have highlighted how financial developments can affect the real economy, particularly through "financial accelerator" effects (Bernanke et al., 1999). Given the dominance of banks in the Philippines, the analysis focuses on bank lending conditions, as in Carabenciov and others 2008). Bank lending $(B L)$ is a function of $B L^{*}$ (defined as the equilibrium level of $B L$ ), the real interest rate gap, and banks' expectation of the economy four quarters ahead. The output gap is explained by the same variables as in equation (1) above as well as by a distributed lag of $\varepsilon_{t}{ }^{B L}$. The values of the coefficients imposed on the distributed lag of $\varepsilon_{t}^{B L}$ are intended to react to a pattern in which an increase of $\varepsilon_{t}{ }^{B L}$ (a loosening of credit conditions) is expected to positively affect spending by firms and households in a hump-shaped fashion, with an initial buildup and then a gradual rundown of the effects as in Carabenciov and others (2008). The specification in this case is:

$$
B L_{t}=B L^{*}-\chi_{\text {RRgap }} \operatorname{RRgap}_{t-1}+\chi_{\text {ygap }} \operatorname{ygap}_{t+4}+\varepsilon_{t}^{B L}
$$

where $\eta$ is the distributed lag of $\varepsilon_{t}^{B L}$ and is calculated as:

$$
\begin{aligned}
& \eta_{t}=0.04 \varepsilon_{t-1}^{B L T}+0.08 \varepsilon_{t-2}^{B L T}+0.12 \varepsilon_{t-3}^{B L T}+0.16 \varepsilon_{t-4}^{B L T}+0.20 \varepsilon_{t-5}^{B L T}+0.16 \varepsilon_{t-6}^{B L T}+0.12 \varepsilon_{t-7}^{B L T} \\
& +0.08 \varepsilon_{t-8}^{B L T}+0.04 \varepsilon_{t-9}^{B L T}
\end{aligned}
$$


- $\quad$ Third, the chapter introduces a pass-through coefficient $p t$ to capture the pass through of international oil price to local fuel prices.

$$
\pi_{t}^{o}=\left(\pi_{t}^{R W o}+4 *\left(z_{t}-z_{t-1}\right)\right) * p t
$$

where $\pi_{t}^{R W o}$ is the international oil price inflation.

Figure 1. Impulse Response to a Global Demand Shock
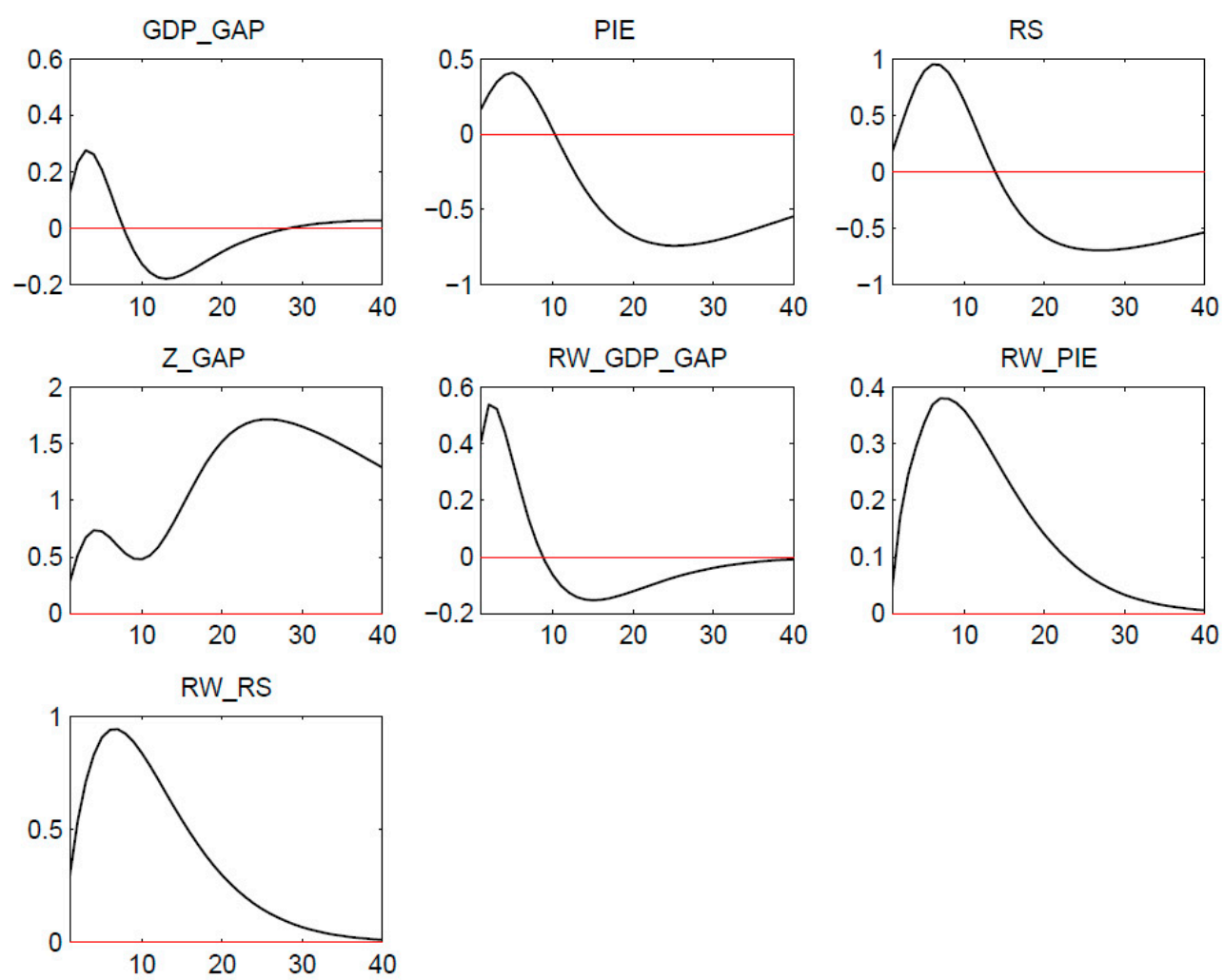
Figure 2. Impulse Response to a Monetary Policy Shock
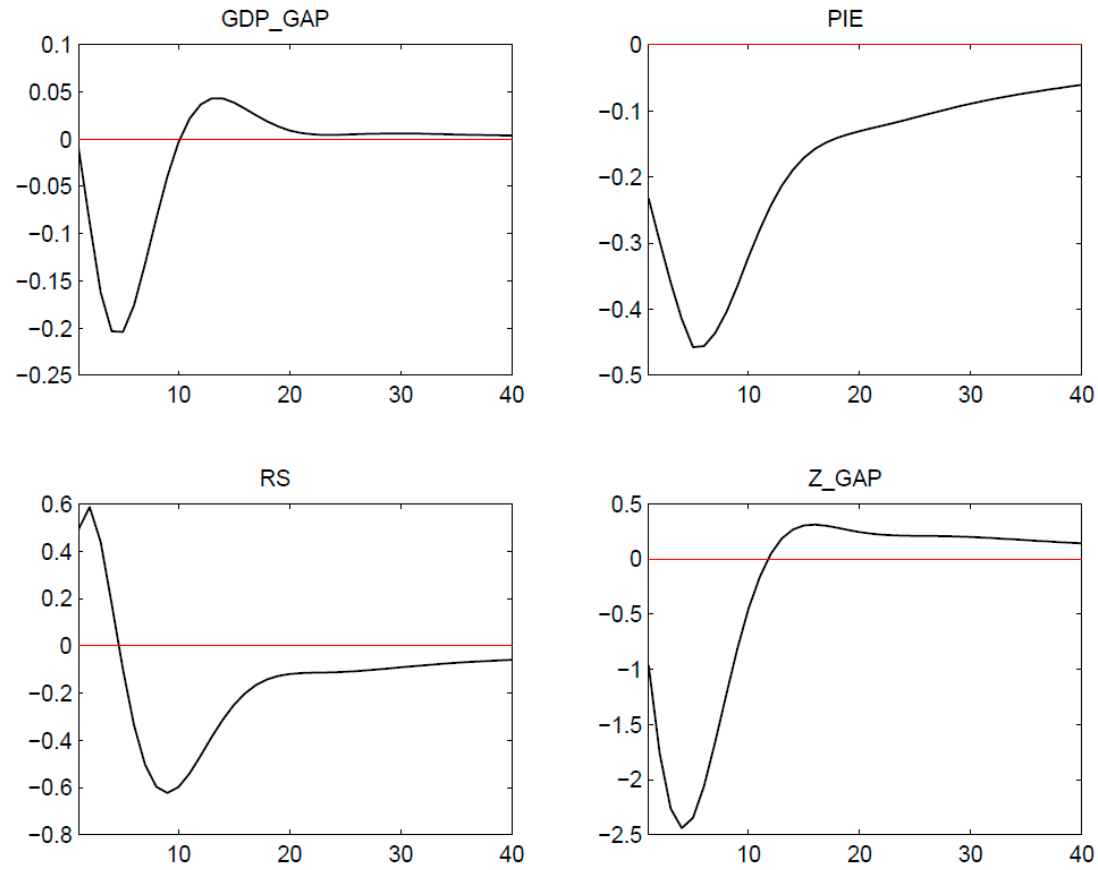

Figure 3. Impulse Response to a Domestic Demand Shock
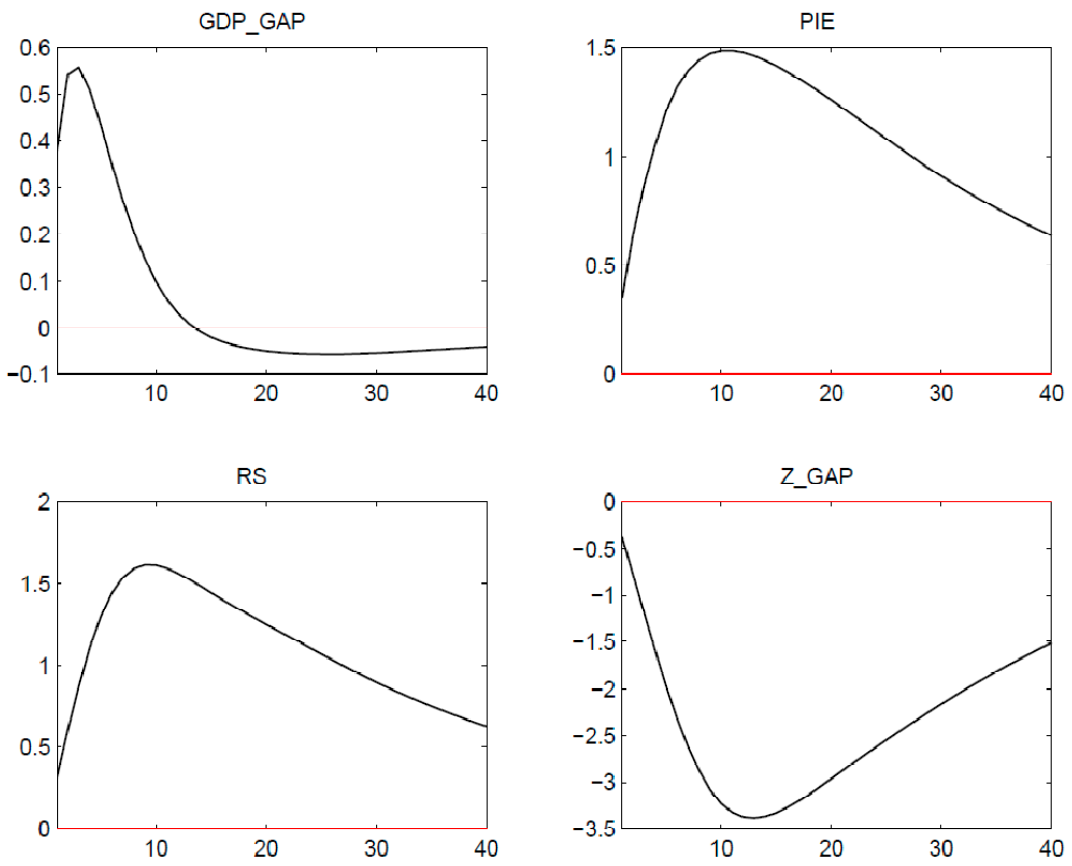


\section{REFERENCES}

Bangko Sentral ng Pilipinas, 2010, “Inflation Report - Third Quarter 2010” (Manila).

Berg, A., P. Karam, and D. Laxton, 2006a, "A Practical Model-Based Approach to Monetary Policy Analysis: Overview,” IMF Working Paper 06/080 (April). Available at www.imf.org

Berg, A., P. Karam, and D. Laxton, 2006b, Practical Model-Based Monetary Policy Analysis: A How-to Guide”, IMF Working Paper 06/081 (April). Available at www.imf.org

Bernanke, B. S., Mark Gertler, and Simon Gilchrist, 1999, "The Financial Accelerator in a Quantitative Business Cycle Framework," in Handbook of Macroeconomics, Volume 1C, Handbooks in Economics, vol. 15. Amsterdam: Elsevier, pp. 1341-93.

Carabenciov, I., I. Ermolaev, C. Freedman, M. Juillard, O. Kamenik, D. Korsunmov, and D. Laxton, 2008, "A Small Multi-Country Global Projection Model with Financial-Real Linkages and Oil Prices," IMF Working Paper No. 08/280 (Washington: International Monetary Fund).

Guinigundo, Diwa C., 2010 "Measurement of Inflation and the Philippine Monetary Policy Framework" in Monetary Policy and the Measurement of Inflation: Prices, Wages and Expectations, BIS Papers No 49. (January 2010).

International Monetary Fund, 2005, "Does Inflation Targeting Work in Emerging Markets?" in World Economic Outlook (September 2005) (Washington).

Keiko, H., and H. Benjamin, 2006, "Stabilizing Inflation in Iceland”, IMF Working Paper 06/262, (Washington: International Monetary Fund).

Kongsamut, Piyabha, 1999, "Philippines: Preparation for Inflation Targeting" IMF Working Paper 01/99 (Washington: International Monetary Fund).

Laxton, Douglas, David Rose and Alasdair M. Scott, 2009, "Developing a Structured Forecasting and Policy Analysis System to Support Inflation-Forecast Targeting (IFT)" (March 2009), IMF Working Papers 09/65 (Washington: International Monetary Fund).

McNelis, Paul D. and Cristeta B. Bagsic., 2007, “Output Gap Estimation for Inflation Forecasting: The Case of the Philippines" BSP Working Paper Series No. 2007-01.

Stone, M. S. Roger, S. Shimizu, A. Nordstrom, J. Restrepo, 2009, "The Role of the Exchange Rate in Inflation-targeting Emerging Economies" (Washington: International Monetary Fund). 


\section{How Would Fiscal Consolidation Affect Growth in the Philippines? ${ }^{1}$}

\section{A. Background}

\section{The Philippines is faced with the dual challenges of increasing development} spending while also lowering the public debt burden, which is among the highest in emerging Asia. Reducing debt and funding needs will require fiscal deficits to be lowered over the medium term. At the same time, low revenues constrain public investment and social spending to among the lowest levels in the region (Figure 1). Increasing spending in a fiscally sustainable manner requires an increase in the revenue effort. A key policy question, therefore, is to what extent fiscal deficits should be reduced over the medium term and how this would affect growth potential. Relatedly, how would a higher revenue effort and increased spending affect growth? These questions are all the more pertinent since growth itself can be a powerful channel for reducing the ratio of debt to GDP.

Figure 1. Key Fiscal Indicators
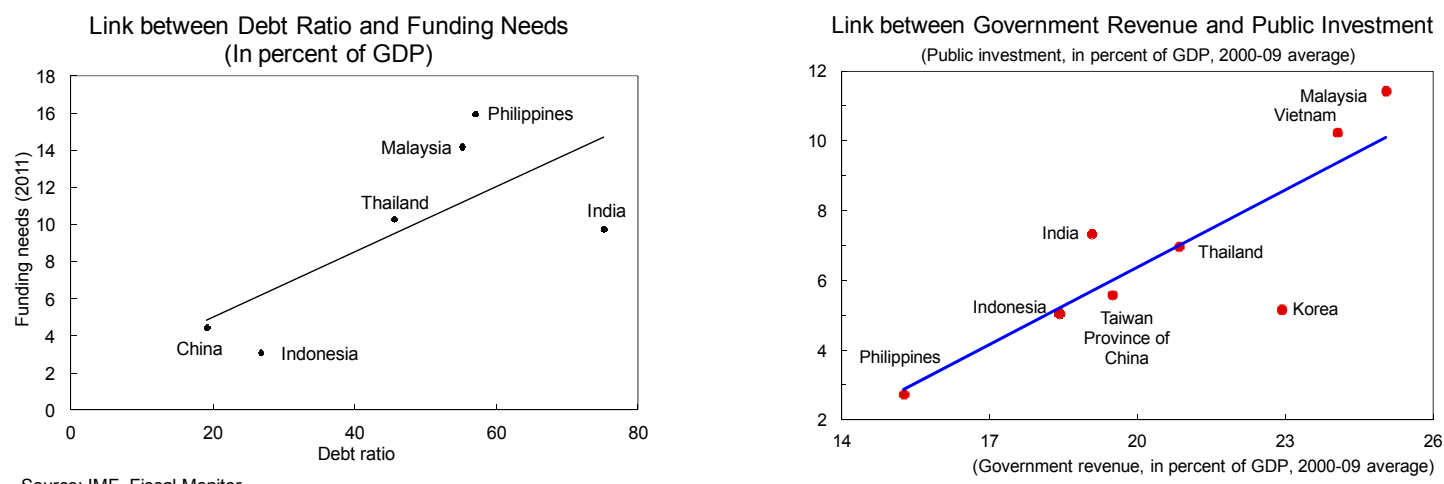

Source: IMF, Fiscal Monitor.

2. To address these questions, this chapter explores the relationship between fiscal consolidation and growth for emerging economies. The chapter seeks to assess the impact of fiscal consolidation on growth in emerging economies, with a particular focus on the role of initial conditions, the composition of revenues and spending consolidation measures and the channels through which consolidation could affect growth. Specifically, the chapter seeks to examine: (i) the relationship between fiscal consolidation and long-term growth; (ii) the impact of the composition of fiscal consolidation on growth; and (iii) the channels through which fiscal consolidation could affect growth. The chapter also explores short-term output dynamics during episodes of large fiscal consolidation.

3. The impact of fiscal consolidation on growth has been studied extensively for OECD countries, but less so for emerging economies. In countries with high debt levels, a number of studies have found fiscal adjustment to have a favorable impact on growth over

${ }^{1}$ Prepared by Anita Tuladhar (FAD). 
the long term. The composition of adjustment has been an important factor in determining the impact on growth. In the OECD countries, the literature has argued that fiscal adjustments could also have a favorable impact on short-run growth, although more recent analysis questions this conclusion. Whether fiscal consolidation can boost short-term growth in emerging economies has been relatively less examined. The impact of the composition of consolidation in emerging economies may also differ from that of advanced economies given the low revenue base and higher spending needs. The channels through which fiscal consolidation affects growth also pose an interesting question, given relatively high openness, especially in countries that have achieved macroeconomic stability.

\section{B. Literature Review}

\section{There are two broad strands of literature on the relationship between fiscal}

policy and growth. The first focuses on the positive relationship between fiscal policy and long-run growth and is based on the foundations of endogenous growth theory in the vein of Barro (1990), King and Rebelo (1990), and Tanzi and Zee (1997). Several empirical papers such as Kneller, Bleaney, and Gemmell (1999) and Baldacci, Clements, Gupta, and Cui (2008) find that reductions in unproductive government spending can be growth enhancing if they are financed by relatively less distortionary taxes, such as consumption taxes, and increases in productive spending.

\section{Another strand of literature focuses on the short-run impact of fiscal} consolidation on growth and finds that the impact depends on the composition of adjustment between revenue and spending. For example, Alesina and Ardagna (2010) find that spending cuts are more effective than tax increases in stabilizing debt and avoiding economic downturns. Gupta and others (2005) present a similar finding for emerging and low-income countries. Several papers argue that large fiscal adjustments through spending cuts can be expansionary (Giavazzi and Pagano (1990), Alesina and Ardagna (1998), Alesina and Perotti (1997), Perotti (1999), Von Hagen, Hallett and Strauch (2001)). In terms of revenues, income taxes fall significantly in expansionary adjustments and rise in contractionary ones. In terms of reducing deficits and debt, successful fiscal adjustments are generally based on spending reductions accompanied by modest tax cuts. These findings on the short-term growth impact of fiscal consolidations are, however, sensitive to the proper identification of the consolidation episodes. Alternative methodologies for identifying consolidation episodes that do not rely on measurement of cyclically adjusted balances find a negative short-term effect of fiscal consolidation in the advanced economies (IMF, 2010a). 


\section{Methodology}

\section{Empirical analysis}

6. Following Gupta and others (2005), the relationship between fiscal consolidation and long-run growth is estimated by regressing annual per capita GDP growth on a set of fiscal variables and other control variables. The baseline regression is as follows:

$$
g_{i t}=u_{i}+\lambda_{t}+\sum_{h=1}^{q} \beta_{h} X G D P_{i h t}+\sum_{l=1}^{k} \beta_{l} Y_{i l t}+v_{i t}
$$

where $g_{i t}$ is the per capita GDP growth rate in country $i$ at time $t ; Y_{i l t}$ is a vector of $k$ control variables that include the initial level of GDP per capita, investment ratio, openness, inflation rate, primary and secondary enrollment rates; and $X G D P_{i h t}$ is a vector of $q$ fiscal variables. In the case of three-year average data, initial data refer to the first year of the threeyear period, whereas in the annual data series initial data refer to the one-period lagged level data. In general, the key fiscal variable is the level of cyclically adjusted fiscal balance as a share of GDP. However, since the estimation of output gaps and cyclically adjusted balances can be highly uncertain in emerging economies, the primary fiscal balance is also often used. The baseline regression here uses the primary fiscal balance.

\section{To understand how the composition of the budget consolidation matters for} growth, different budget components are used as an alternative for the fiscal variables. In particular, a breakdown into revenue and spending components, including cyclically adjusted revenues and cyclically adjusted expenditures, are used as the fiscal variables in the vector $X G D P_{i h t}$. Where data are available, a further breakdown into sub-components such as wages, transfers and subsidies, spending on goods and services, capital expenditures, tax and non-revenues, and grants are also used. $u_{i}$ represents country dummies and $\lambda_{t}$ are time dummies. To control for endogeneity between the fiscal variables and growth, the generalized method of moments (GMM) is used as the baseline methodology.

\section{Data}

8. Since a key objective of the study is to examine output dynamics during periods of fiscal consolidation in emerging economies, the sample includes countries that have undergone large fiscal consolidations. A recent IMF paper (IMF, 2010b) has identified episodes of fiscal consolidation in advanced and emerging economies based on changes in cyclically adjusted primary balances (Table A1). A large fiscal consolidation episode is defined as a period during which cyclically adjusted primary balances improve continuously without reversing by more than 1 percent of GDP. The chapter draws from this set of emerging market economies, covering annual data for a maximum period from 1980 through 2008. Summary statistics of some of the key data used in the regression are shown below (Table 1). Although the sample includes periods of large consolidations, the mean and 
median values for fiscal balances and for macroeconomic indicators for the full data sample do not deviate significantly from that of the Philippines. Hence, even though the Philippines is not considered a "large consolidation" case, the empirical findings from the sample remain relevant for the Philippines. Correlations based on cross-country data suggest a positive relationship between growth and both the overall balance and the primary balance (Figure 2).

Table 1. Summary Statistics of Key Selected Data (In percent; shares of GDP unless noted otherwise)

\begin{tabular}{lccccc}
\hline & Mean & Median & Std. Dev. & Observations & Source \\
\cline { 2 - 6 } Per Capita GDP Growth & 2.0 & 2.5 & 5.6 & 776 & WEO \\
Fiscal Primary Balance to GDP & 1.0 & 1.1 & 2.9 & 326 & WEO \\
Cyclically Adjusted Primary Balance to GDP & 0.7 & 0.7 & 4.4 & 669 & WEO \\
Fiscal Balance to GDP & -2.7 & -2.4 & 4.1 & 370 & WEO \\
Revenue to GDP & 26.0 & 25.3 & 8.3 & 393 & WEO \\
Primary Expenditure to GDP & 25.3 & 24.1 & 8.4 & 329 & WEO \\
Inflation & 22.9 & 8.6 & 46.7 & 776 & WEO \\
Openness & 52.1 & 46.0 & 32.7 & 793 & WEO \\
Private Investment to GDP & 15.8 & 15.3 & 5.2 & 683 & WEO \\
& & & & & \\
\hline
\end{tabular}

Sources: WEO; and IMF staff estimates.

Note: For detailed data source, see Appendix Table A2.

Figure 2. Correlations between Fiscal Variables (as percent of GDP) and Per Capita GDP Growth
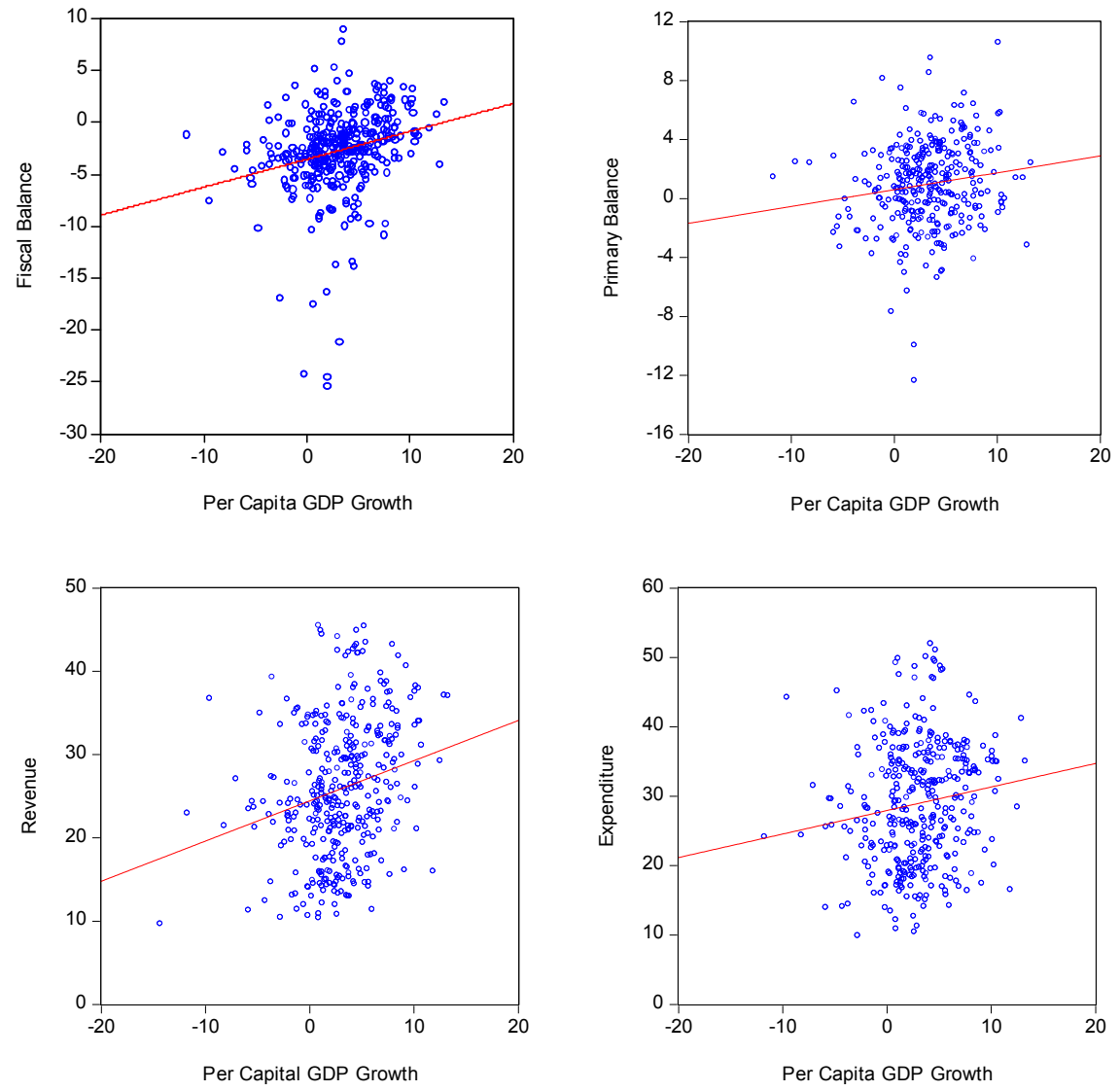

Sources: WEO; and IMF staff estimates. 


\section{Regression Results}

\section{Fiscal consolidation and long-run growth}

9. The positive association between fiscal balance and growth is evident across a range of methodologies. A panel GMM is used as the baseline model (Table 2, column 5), but alternative methodologies are also used that include pooled OLS (column 1), GLS (column 2), and two-way fixed effects models (column 3) (Table 2). Since none of these three methods controls for potential endogeneity of the fiscal variables, two alternative estimation methods are adopted. First, non-overlapping three-year average data are used to address potential business cycle effects (column 4); and, second, panel GMM is run with two to three period lags of the explanatory variables used as instruments (column 5).

Table 2. Per Capita GDP Growth and Primary Fiscal Balance

\begin{tabular}{|c|c|c|c|c|c|c|c|c|}
\hline \multicolumn{9}{|c|}{ Dependent Variable: Per Capita GDP Growth } \\
\hline \multirow{2}{*}{$\begin{array}{l}\text { Explanatory Variables } \\
\text { (percent of GDP, unless noted) }\end{array}$} & \multicolumn{2}{|c|}{1} & 2 & \multicolumn{2}{|c|}{3} & \multicolumn{2}{|c|}{4} & 5 \\
\hline & $\mathrm{O}$ & & GLS & $\mathrm{F}$ & & $\begin{array}{r}\text { aver } \\
\end{array}$ & year & Panel GMM \\
\hline Constant & -1.24 & & -1.15 & 1.14 & & 3.74 & & \\
\hline Lagged Per Capita GDP (level) & 0.00 & & $0.00 \quad(* *)$ & 0.00 & $(*)$ & 0.00 & $(* *)$ & $(* * *)$ \\
\hline Fiscal Primary Balance to GDP & 0.22 & $(* * *)$ & $0.26(* * *)$ & 0.34 & $(* * *)$ & 0.33 & $(* *)$ & 0.40 \\
\hline Inflation (annual rate) & -0.05 & & $-0.04 \quad(*)$ & -0.05 & & 0.00 & & -0.19 \\
\hline Openness & 0.01 & & 0.01 & -0.02 & & -0.02 & & -0.02 \\
\hline Private Investment & 0.25 & $(* * *)$ & $0.26 \quad(* * *)$ & 0.28 & $(* * *)$ & 0.17 & & 0.37 \\
\hline R-squared & 0.20 & & 0.39 & 0.55 & & 0.84 & & \\
\hline Adjusted R-squared & 0.18 & & 0.38 & 0.45 & & 0.71 & & \\
\hline S.E. of regression & 3.40 & & 3.38 & 2.79 & & 1.59 & & 3.48 \\
\hline Total (unbalanced) observations & 311 & & 311 & 311 & & 83 & & 273 \\
\hline
\end{tabular}

Source: IMF staff estimates.

$\left({ }^{* * *}\right)$ denotes significance level at 99 percent; $\left({ }^{* *}\right)$ denotes significance level at 95 percent; $\left({ }^{*}\right)$ denotes significance level at 90 percent. Instruments are based on two and three period lags of the explanatory variables for GMM estimation.

10. These methods suggest that an increase in primary fiscal balance by 1 percentage point of GDP is associated with higher per capita GDP growth by 0.2 to 0.4 percentage points. This result is similar to that of Gupta and others (2005) that finds a coefficient of 0.25 and Kneller and others (1999) that finds a coefficient of 0.4. Using fiscal balances instead of primary balances also yields a significant positive relationship with growth (Table 3, column 2). Cyclically adjusted primary balances, however, do not have a significant effect on growth (Table 3, column 3). For control variables, as expected, inflation is negatively correlated with long-run growth, while the private investment ratio is positively correlated with growth. Openness, measured as the sum of exports and imports to GDP, turns out not to be statistically significant. Educational enrollment variables also turn out not to be significant. 


\section{Composition of fiscal consolidation and long-run growth}

11. Panel regressions show that the composition of fiscal consolidation can be an important factor in determining the impact on growth. The baseline regression is repeated with fiscal balances substituted by their components in terms of revenue and spending (Table 3, columns 4-5). The revenue to GDP ratio does not show a significant relationship with growth, whereas both primary and overall spending to GDP ratios are negatively correlated with growth. The negative association is significant and robust to alternative specifications. A further breakdown of revenue into tax and non-tax components also shows that, while the coefficients on revenue components remain insignificant, spending remains negatively correlated with growth (Table 3, columns 6-7).

12. The negative relationship between primary spending and growth suggests that the quality of spending has important implications. Although data limitations preclude a robust analysis, a decomposition of the spending items shows that current spending such as wages and transfers are negatively related to growth (Table 3 , column 8 ). These types of spending are often considered to be less productive relative to other types of public spending, including public investment. Indeed, capital spending, which is considered to be more productive provided project appraisal and selection are well-managed, is found to have a significant positive impact on growth.

\section{Although the impact of revenue on growth is somewhat ambiguous, tax revenue} appears to be positively associated with growth whereas non-tax revenue is negatively associated with growth. The positive association between tax revenue and growth stands in contrast to studies for advanced economies, and may reflect the greater reliance in emerging economies on indirect taxes which have a less distortionary impact on labor supply and investment decisions than direct taxes. Furthermore, since initial tax levels are often relatively low in emerging economies, an increase in tax revenues can increase the scope for higher growth enhancing spending.

\section{E. Channels of Transmission to Growth}

14. A key channel through which higher fiscal balances may enhance growth is by lowering borrowing costs and "crowding in" private investment. A Vector Autoregression (VAR) model with country specific fixed effects is used to examine the effect of fiscal shocks on macroeconomic variables such as government borrowing rates and private investment. ${ }^{2}$ The government borrowing rate is measured by the average annual

\footnotetext{
${ }^{2}$ The VAR uses a Choleski decomposition of the shocks based on the following ordering of the variables: $\left[\mathrm{X}_{\mathrm{t}}=\right.$ Cyclically Adjusted Primary Balance, Inflation Rate, Real Effective Exchange Rate, Government Borrowing Rate, Investment Rate, Per capita GDP Growth Rate]. A lag of four periods is used in the regressions based on the Akaike information criteria and the Schwartz criteria.
} 
Table 3. Per Capita GDP Growth and Fiscal Composition

\begin{tabular}{|c|c|c|c|c|c|c|c|c|}
\hline \multicolumn{9}{|l|}{ Dependent Variable: Per Capita GDP growth } \\
\hline Explanatory Variables & 1 & 2 & 3 & 4 & 5 & 6 & 7 & 8 \\
\hline (percent of GDP, unless noted) & GMM & GMM & GMM & GMM & GMM & GMM & GMM & GMM \\
\hline Per capita GDP growth(-1) (annual rate) & -0.08 & 0.21 & -0.06 & -0.10 & -0.08 & -0.32 & -0.32 & $-0.37(* * *)$ \\
\hline Per capita GDP growth (-2) (annual rate) & 0.00 & -0.04 & -0.01 & 0.01 & -0.01 & -0.05 & -0.06 & 0.02 \\
\hline Initial Per Capita GDP (level) & $0.00 \quad(* * *)$ & $0.00 \quad(* *)$ & $0.00 \quad(* * *)$ & $0.00 \quad(* * *)$ & $0.00(* * *)$ & $0.00(* * *)$ & $0.00(* * *)$ & $0.00 \quad(* *)$ \\
\hline Primary Fiscal Balance & $0.40 \quad(* *)$ & & & & & & & \\
\hline Cyclically Adjusted Primary Balance & & -0.04 & & & & & & \\
\hline Fiscal Balance & & & $0.36 \quad(* *)$ & & & & & \\
\hline Revenue & & & & -0.02 & -0.06 & & & \\
\hline Primary Expenditure & & & & $-0.48 \quad(* *)$ & & $-0.24(* *)$ & & \\
\hline Expenditure & & & & & $-0.42(* *)$ & & $-0.26(* * *)$ & \\
\hline Tax Revenue & & & & & & 0.20 & 0.23 & $1.18(* * *)$ \\
\hline Non Tax Revenue & & & & & & -0.24 & -0.24 & $-1.11(* * *)$ \\
\hline Capital Expenditure & & & & & & & & $0.43 \quad(*)$ \\
\hline Goods and Services & & & & & & & & 0.11 \\
\hline Wages & & & & & & & & $-2.90(* * *)$ \\
\hline Transfers & & & & & & & & -2.10 \\
\hline Inflation (annual rate) & $-0.19(* * *)$ & $-0.03(* *)$ & $-0.18(* * *)$ & $-0.22(* * *)$ & $-0.20(* * *)$ & $-0.18(* *)$ & $-0.17 \quad(*)$ & $-0.46(* * *)$ \\
\hline Openness & -0.02 & 0.05 & 0.01 & 0.01 & 0.03 & -0.09 & -0.09 & -0.20 \\
\hline Private Investment & $0.37(* * *)$ & 0.05 & $0.31(* * *)$ & $0.33 \quad(* * *)$ & $0.27(* * *)$ & $0.60(* * *)$ & $0.56(* * *)$ & $0.64 \quad(*)$ \\
\hline S.E. of regression & 3.48 & 5.10 & 3.45 & 3.41 & 3.38 & 3.18 & 3.16 & 2.29 \\
\hline Number of Observations & 273 & 522 & 296 & 273 & 296 & 169 & 169 & 48 \\
\hline
\end{tabular}

Source: IMF staff estimates.

$\left.{ }^{(* \star}\right)$ denotes significance level at 99 percent; $\left({ }^{* \star}\right)$ denotes significance level at 95 percent; $\left({ }^{\star}\right)$ denotes significance level at 90 percent. Instruments are based on two- and three- period lags of the explanatory variables. 
interest rate on 5-year or 10-year government bonds, where available, and by the T-bill rate otherwise. The impulse response functions of a shock to fiscal balances suggest the presence of a crowding-in effect (Figure 3). As expected, a tightening of fiscal policy shown by an improvement in the cyclically adjusted primary balance leads to a lower inflation rate. It is also associated with a lower government borrowing rate, and an increase in private investment rates and per-capita growth.

Figure 3. Impulse Response of Macroeconomic Variables to a Fiscal Shock
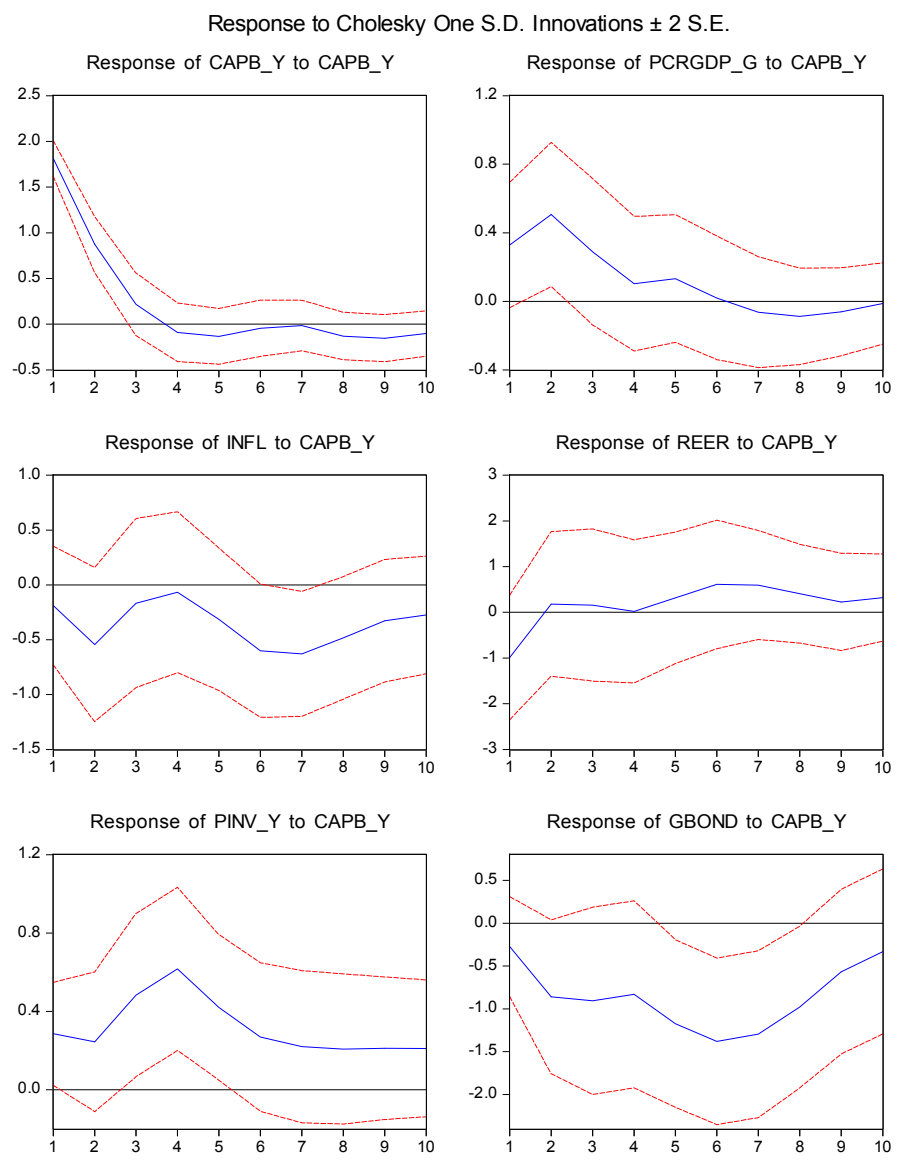

Source: IMF staff estimates.

Note: CAPB_Y denotes cyclically adjusted primary balance to GDP; PCRGDP_Y, per capita GDP growth; INFL, inflation; REER, real effective exchange rate; PINV_Y, private investment to GDP; GBOND, government borrowing rate.

15. To further disentangle the effects of revenue and expenditure shocks, fiscal shocks are disaggregated into cyclically adjusted revenue and cyclically adjusted expenditure shocks. As discussed above, spending shocks are not associated with higher growth whereas revenue shocks are positively correlated with growth (Figure 4). Higher spending raises interest rates and crowds out private investment, while a revenue shock crowds in private investment and raises growth. 
Figure 4. Crowding Out Effects of Revenue and Spending Shocks

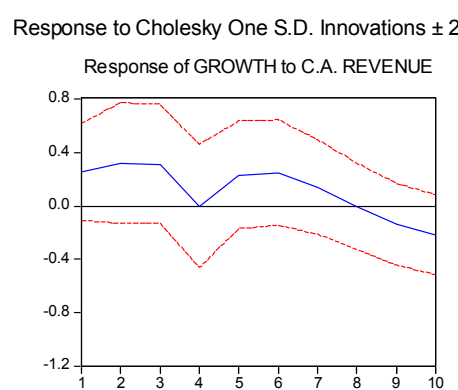

Response of GROWTH to C.A. PRIMARY EXPENDITURE

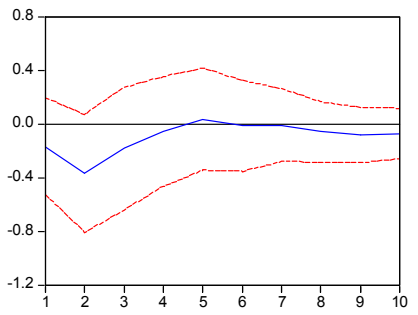

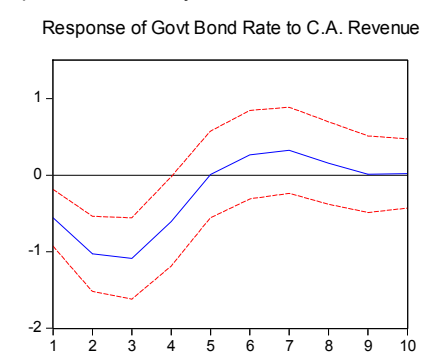

Response of Govt Bond Rate to C.A. Primary Expenditure

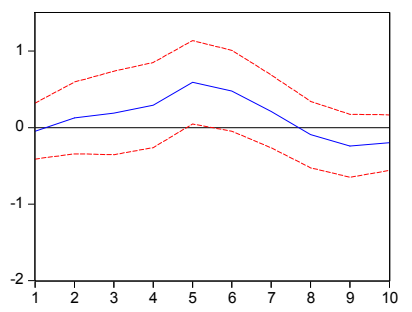

Response to Cholesky One S.D. Innovations \pm 2 S.E.

Response of Private Investment to C.A. Revenue

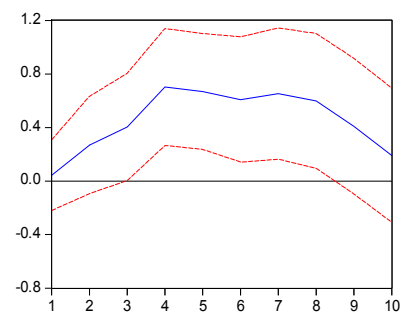

Response of Private Investment to C.A. Primary Expenditure

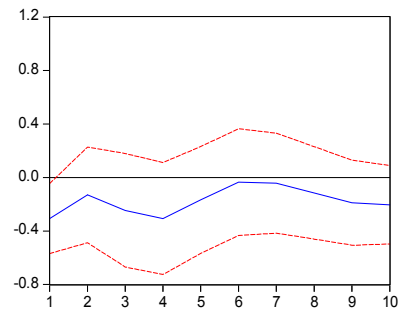

Source: IMF staff estimates.

Note: C.A. denotes cyclically adjusted.

\section{F. Fiscal Consolidation and Short-Run Growth}

\section{An important policy question is whether fiscal consolidation can lead to output}

losses in the short term. The fiscal and macroeconomic dynamics during large consolidation episodes are compared with those during the three preceding years ("the pre-consolidation period") and the three succeeding years ("the post-consolidation periods"). On average, in the sample, cyclically adjusted fiscal balances improve by around 4 percent of GDP compared to the pre-consolidation period, and these improvements are sustained during the postconsolidation period. The consolidation is achieved through revenue as well as spending adjustments. In the post-consolidation period, expenditures rise and are accommodated through increased revenues.

\section{Short-run output dynamics suggest that these large consolidations are not} necessarily contractionary. On average, growth is slightly higher during the consolidation episodes compared with the pre-consolidation episodes (Figure 5) and growth improves more substantially during the post-consolidation period. 
Figure 5. Emerging Economies: Fiscal Consolidation Episodes and Growth

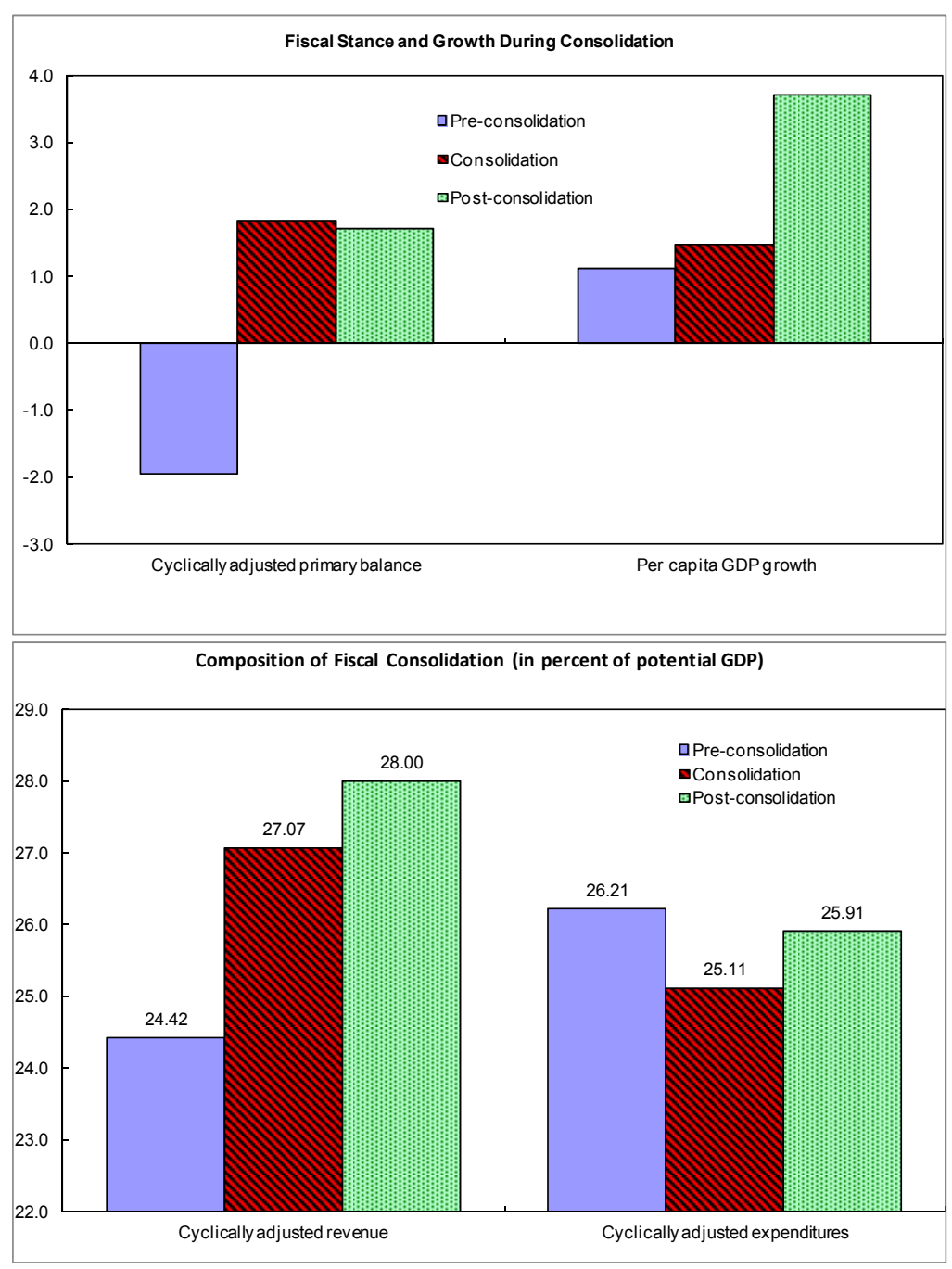

Sources: WEO; and IMF staff estimates.

Notes: Pre-consolidation period refers to three years before the consolidation period and post-consolidation period refers to three years after. Consolidation episodes are the large adjustment episodes as described in IMF (2010a). For a given consolidation episode, cyclically adjusted primary balances should not reverse by more 1 percentage point of GDP.

\section{Output dynamics during the consolidation episodes depend, however, upon}

initial conditions. The sample of countries can be separated into groups with weaker and with stronger initial conditions. Weaker (stronger) initial conditions are defined as those with initial growth lower (higher) than the sample average of 1.1 percent, or with inflation above (below) 18.5 (5) percent or debt higher (lower) than 40 percent of GDP during the preconsolidation period. Compared with pre-consolidation periods, average growth in countries with weaker initial conditions improves significantly during the consolidation period (Figure 6). In countries with stronger initial conditions, the improvement in growth is less marked and there is even a slight slowdown during the consolidation period. 
Figure 6. Emerging Economies: Fiscal Stance, Growth and Initial Conditions

Low-Growth Countries

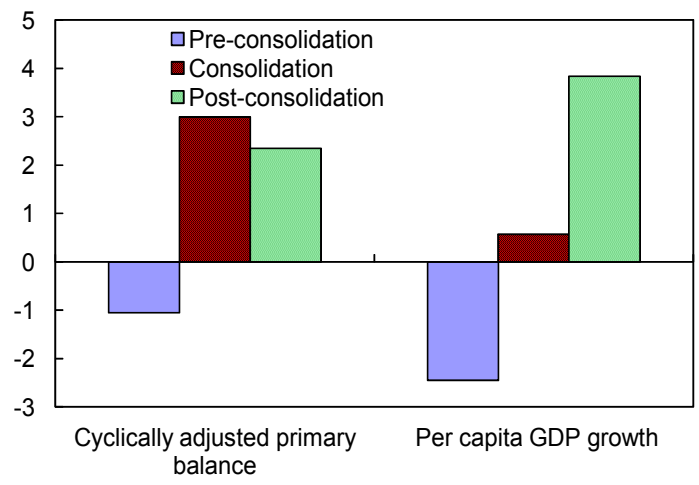

High-Inflation Countries

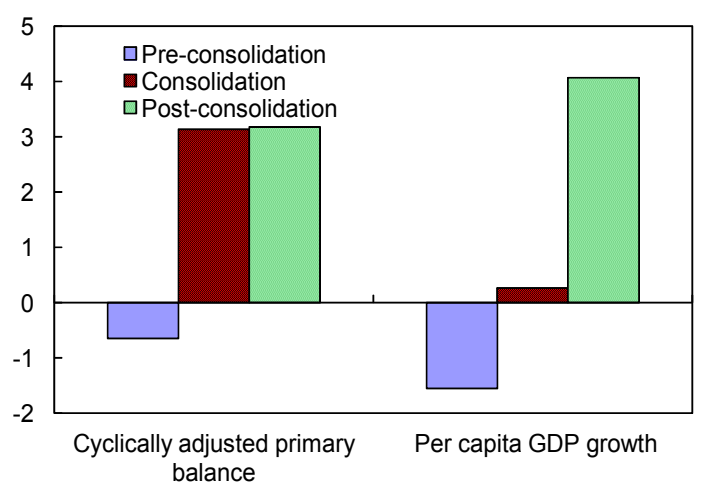

High-Debt Countries

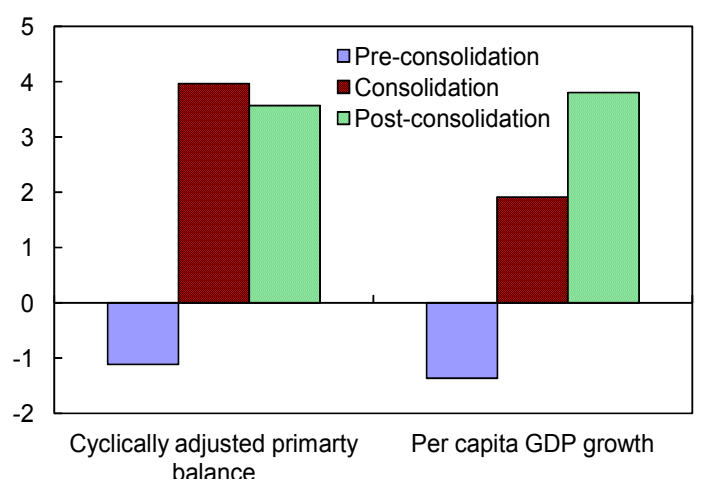

High-Growth Countries

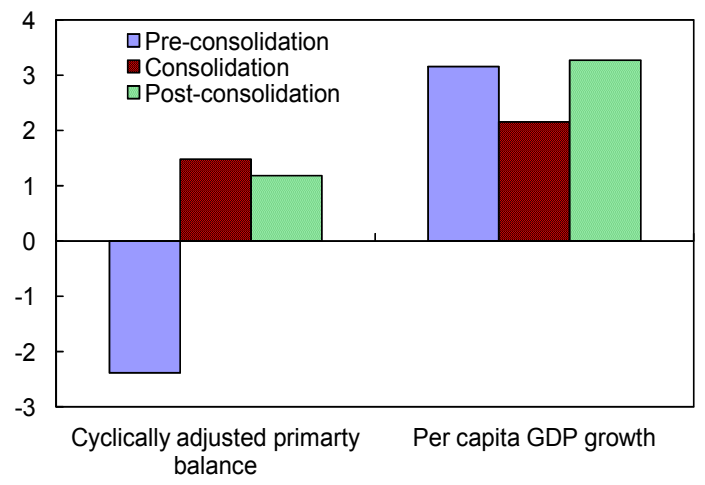

Low-Inflation Countries

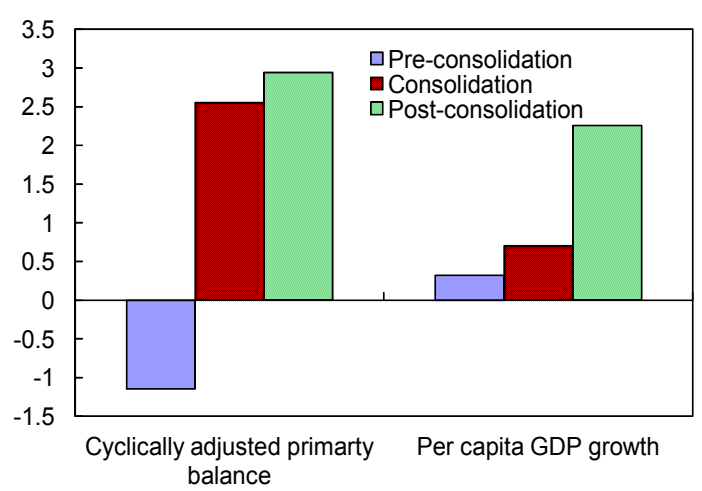

Low-Debt Countries

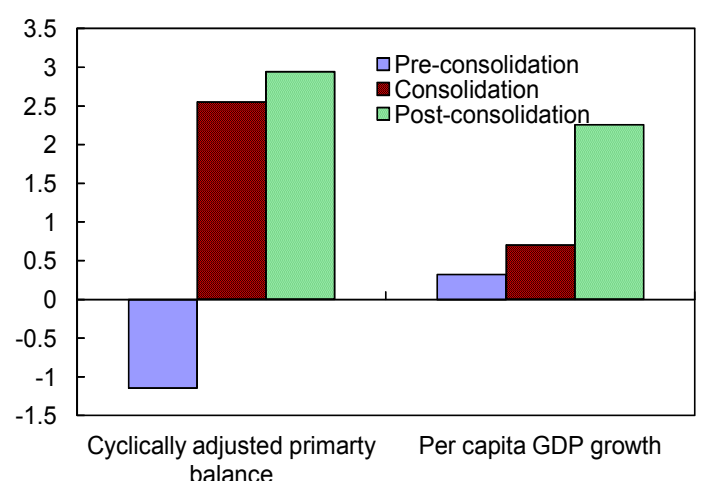

Sources: WEO; and IMF staff estimates.

Notes: Low (high) growth economies represent countries with per capita growth below(above) sample average of 1.1 percent during the pre-consolidation period. High inflation economies represent countries with inflation above sample average of 18.5 percent during the pre-consolidation period. Low inflation economies represent countries with inflation below 5 percent during the pre-consolidation period. High (low) debt economies represent countries with debt to GDP ratio above (below) 40 percent of GDP during the pre-consolidation period. 


\section{To examine whether the composition of adjustment matters for growth, the} countries are grouped into those that experienced an increase in growth relative to the pre-consolidation period and those that experienced a decline. The size of the adjustment is similar between the two groups at about 3-4 percent of GDP (Table 4). In both groups, the adjustment is revenue-based, with the revenue to GDP ratio rising by $2 \frac{1}{2}$ percent of GDP in the expansionary episodes and 5 $\frac{1}{2}$ percent of GDP in the contractionary episodes. However, the expenditure adjustment differs: in the high growth cases, the adjustment is expenditurebased whereas in the lower-growth cases, expenditure ratio tends to increase. These trends are consistent with studies that argue that cuts in less productive spending such as transfers, subsidies, and wages are more credible and generate more confidence.

Table 4. Composition of Adjustment in Expansionary versus Contractionary Episodes (In percent of GDP, unless noted otherwise)

\begin{tabular}{|c|c|c|c|c|}
\hline \multicolumn{5}{|c|}{ Expansionary Episodes } \\
\hline & $\begin{array}{l}\text { Per Capita } \\
\text { Growth } \\
\text { (in percent) }\end{array}$ & $\begin{array}{l}\text { Cyclically } \\
\text { Adjusted } \\
\text { Primary } \\
\text { Balance }\end{array}$ & $\begin{array}{l}\text { Cyclically } \\
\text { Adjusted } \\
\text { Revenue }\end{array}$ & $\begin{array}{c}\text { Cyclically } \\
\text { Adjusted } \\
\text { Primary } \\
\text { Expenditure }\end{array}$ \\
\hline Pre-consolidation & -0.3 & -1.4 & 27.3 & 28.7 \\
\hline Consolidation & 2.7 & 2.5 & 29.9 & 27.4 \\
\hline Change & 3.0 & 3.9 & 2.6 & -1.4 \\
\hline \multicolumn{5}{|c|}{ Contractionary Episodes } \\
\hline & $\begin{array}{l}\text { Per Capita } \\
\text { Growth } \\
\text { (in percent) }\end{array}$ & $\begin{array}{l}\text { Cyclically } \\
\text { Adjusted } \\
\text { Primary } \\
\text { Balance }\end{array}$ & $\begin{array}{l}\text { Cyclically } \\
\text { Adjusted } \\
\text { Revenue }\end{array}$ & $\begin{array}{c}\text { Cyclically } \\
\text { Adjusted } \\
\text { Primary } \\
\text { Expenditure }\end{array}$ \\
\hline Pre-consolidation & 2.3 & -2.3 & 19.3 & 21.6 \\
\hline Consolidation & 0.0 & 1.0 & 24.7 & 23.7 \\
\hline Change & -2.3 & 3.3 & 5.4 & 2.1 \\
\hline
\end{tabular}

Source: IMF staff estimates.

\section{These findings suggest that short-run output effects of fiscal consolidation in the} Philippines would likely depend on the composition of adjustment. Since the Philippines has already achieved macroeconomic stability, the implications of initial conditions for shortrun growth is somewhat mixed: the high initial debt level suggests fiscal consolidation would lead to higher growth, but low inflation (below 4 percent) and high initial growth (7 percent) conditions suggest that growth effects would be muted or even slightly contractionary. The authorities' medium-term consolidation plan envisages increased revenues to finance higher expenditures. Given the low revenue base in the Philippines, an increase in revenues should not lead to a slowdown in growth, especially if accompanied by expenditure reforms that continue to improve the share of productive spending. The impact of fiscal consolidation on growth will thus depend to a large degree on the quality of spending. 


\section{G. Conclusion}

\section{The empirical analysis shows a generally positive impact of higher fiscal}

balances on growth over the long run. In the short run, the growth impact depends on initial conditions and the composition of consolidation measures. Higher spending is not necessarily growth enhancing, particularly, current spending. Revenue increases, however, can be growth friendly by improving confidence and by allowing more productive spending. A key channel through which fiscal consolidation seems to affect growth is the crowding in of private investment. Notably, revenue increases reduce interest rates and encourage private investment, whereas expenditure increases crowd out private investment. These findings suggest that medium-term fiscal consolidation could crowd in private investment and raise growth over the longer run in the Philippines even if the short-term impact on growth is less clear. The composition of consolidation is important: maintaining the quality of revenue and spending measures is crucial to maximize growth. 


\section{APPENDIX}

Table A1. Country Sample with Large Fiscal Consolidations

\begin{tabular}{|c|c|c|c|}
\hline Country & Beginning Year & End Year & Number of Years \\
\hline Argentina & 2002 & 2004 & 3 \\
\hline Barbados & 2003 & 2005 & 3 \\
\hline Brazil & 1998 & 2003 & 6 \\
\hline Bulgaria & 1994 & 1996 & 3 \\
\hline Chile & 2000 & 2007 & 8 \\
\hline Colombia & 1998 & 2005 & 8 \\
\hline Costa Rica & 1990 & 1992 & 3 \\
\hline Dominican Republic & 1990 & 1992 & 3 \\
\hline Egypt & 1985 & 1987 & 3 \\
\hline El Salvador & 1993 & 1997 & 5 \\
\hline Estonia & 2000 & 2003 & 4 \\
\hline Georgia & 1995 & 2004 & 10 \\
\hline Hungary & 1994 & 1996 & 3 \\
\hline Jamaica & 1984 & 1989 & 6 \\
\hline Jordan & 1988 & 1990 & 3 \\
\hline Lebanon & 1997 & 1999 & 3 \\
\hline Lithuania & 2000 & 2005 & 6 \\
\hline Mexico & 1982 & 1984 & 3 \\
\hline Morocco & 1983 & 1988 & 6 \\
\hline Pakistan & 1992 & 2003 & 12 \\
\hline Panama & 1983 & 1986 & 4 \\
\hline Paraguay & 1982 & 1990 & 9 \\
\hline Peru & 2000 & 2007 & 8 \\
\hline Romania & 1980 & 1984 & 5 \\
\hline Slovak Republic & 1993 & 1995 & 3 \\
\hline South Africa & 1993 & 1999 & 7 \\
\hline Tunisia & 1984 & 1989 & 6 \\
\hline Turkey & 1988 & 1990 & 3 \\
\hline Ukraine & 1998 & 2000 & 3 \\
\hline Uruguay & 2000 & 2006 & 7 \\
\hline
\end{tabular}

Source: IMF (2010b) 


\section{Table A2. Data Sources}

\begin{tabular}{|c|c|c|}
\hline Label & Description & Source \\
\hline capb_y & Cyclically adjusted primary balance as a share of GDP & Exit paper database \\
\hline rgdp & Real GDP & WEO \\
\hline rgdp_g & Real GDP growth & calculated \\
\hline pcrgdp & Per capita real GDP & WEO \\
\hline pcrgdp_g & Per capita real GDP growth & calculated \\
\hline infl & Inflation (annual average) & WEO \\
\hline inv_y & Investment ratio to GDP & WEO \\
\hline penroll & Primary school enrollment rate & WDI \\
\hline senroll & Secondary school enrollment rate & WDI \\
\hline open & Trade openness (sum of export and import to GDP) & WDI \\
\hline fisc_bal_y & Fiscal balance as a share of GDP & WEO \\
\hline fisc_pbal_y & Primary fiscal balance as a share of GDP & WEO \\
\hline rev_y & Revenue as a share of GDP & WEO \\
\hline exp_y & Expenditure as a share of GDP & WEO \\
\hline tax_y & Tax revenue to GDP & WEO \\
\hline ntax_y & Non-tax revenue to GDP & WEO \\
\hline grant_y & Grants to GDP & WEO \\
\hline wage_y & Wages to GDP & WEO \\
\hline transf_y & Transfers to GDP & WEO \\
\hline subs_y & Subsidies to GDP & WEO \\
\hline GS_Y & Other spending on goods and servicse to GDP & WEO \\
\hline capex_y & Capital expenditures to GDP & WEO \\
\hline debt_y & Debt to GDP & WEO \\
\hline GovtBond & Long-term bond yield & \\
\hline Tbill_IFS & Treasury bill rate from IFS - see EDSS6 for details & IFS \\
\hline bloomberg_m3 & Treasury bill rate from bloomberg - short coverage (short-term) & Bloomberg \\
\hline bloomberg_y10 & Treasury bill rate from bloomberg - short coverage (long-term) & Bloomberg \\
\hline exp_int & Expenditure on interest rates & WEO \\
\hline reer & Real exchange rate & INS \\
\hline er & Nominal exchange rate & INS \\
\hline gap & Output Gap & Exit paper database \\
\hline cyc_rev & Cyclically adjusted revenue & Exit paper database \\
\hline cyc_pexp & Cyclically adjusted primary expenditure & Exit paper database \\
\hline cyc_exp & Cyclically adjusted expenditure & Exit paper database \\
\hline
\end{tabular}




\section{REFERENCES}

Alesina, Alberto, and Silvia Ardagna, 2009, "Large Changes in Fiscal Policy: Taxes versus Spending,” NBER Working Paper 15438, (Cambridge, Massachusetts: National Bureau of Economic Research).

— 1998, “Tales of Fiscal Adjustment,” Economic Policy, Vol. 27 (October), pp. 487-546.

Alesina, Alberto, and Roberto Perotti, 1996, "Fiscal Adjustments in OECD Countries: Composition and Macroeconomic Effects,” NBER Working Paper No. 5730.

Baldacci, Emanuele, Benedict Clements, Sanjeev Gupta and Li Cui, 2008, "Social Spending, Human Capital, and Growth in Developing Countries," World Development Vol. 36, No. 8 pp 1317-1341.

Barro, Robert, 1990, "Government Spending in a Simple Model of Endogenous Growth," Journal of Political Economy, Vol. 98(1), pp. 103-17.

Baldacci, Emanuele, Benedict Clements, Sanjeev Gupta, and Carlos Mulas-Granados, 2005, "Expenditure Composition, Fiscal Adjustment, and Growth in Low-Income Countries," JIMF, 24(3), 441-463.

International Monetary Fund, 2010a, "Will it Hurt? Macroeconomic Effects of Fiscal Consolidation,” World Economic Outlook November 2010 (Washington).

International Monetary Fund, 2010b, "Strategies for Fiscal Consolidation in the Post-Crisis World," IMF Policy Paper (Washington).

King, Robert and Sergio Rebelo, 1990, "Public Policy and Economic Growth: Developing Neoclassical Implications," NBER Working Paper 3338 (Cambridge, Massachusetts: National Bureau of Economic Research).

Kneller, Richard, Michael F. Bleaney and Norman Gemmell, 1999, "Fiscal Policy and Growth: Evidence for OECD Economies,” Journal of Public Economics, Vol. 74, pp. 171-190.

Kumar, Mohan, Daniel Leigh and Alexander Plekhanov, 2007, "Fiscal Adjustments: Determinants and Macroeconomic Consequences," IMF Working Paper 07/178 (Washington: International Monetary Fund).

Perotti, Roberto, 1998, The Political Economy of Fiscal Consolidations," Scandinavian 
Journal of Economics. Vol. 100(1), pp. 367-94.

Tanzi, Vito and Howell Zee, 1996, "Fiscal Policy and Long-Run Growth,” IMF Working Paper 96/119 (Washington: International Monetary Fund).

Von Hagen, J., A. Hallett, and R. Strauch, 2002, "Budgetary Consolidation in Europe: Quality, Economic Conditions, and Persistence," Journal of the Japanese and International Economies, Vol. 16, No. 512-35. 